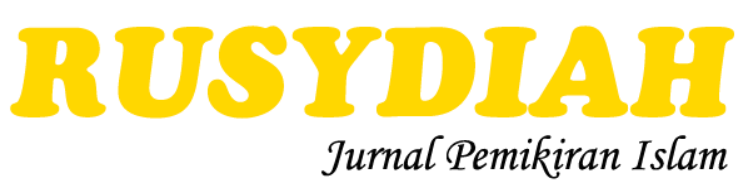

Volume 2 Nomor 2, Desember 2021

ISSN: 2723-4894 (cetak), ISSN: 2723-4886 (daring)

DOI: https://doi.org/10.35961/rsd.v2i2.291

\title{
PERKEMBANGAN ILMU SYARAH HADITH: SUATU TELAAH RINGKAS
}

\author{
Ahmad Nabil Amir \\ International Institute of Islamic Thought and Civilization (ISTAC-IIUM) \\ nabiller2002@gmail.com \\ Tasnim Abdul Rahman \\ Universiti Sultan Zainal Abidin (UniSZA) Terengganu \\ tasnimrahman@unisza.edu.my
}

\begin{abstract}
Abstrak
Kertas ini membahaskan secara terperinci perkembangan ilmu syarah sejak kurun terawal Hijrah. Ia membincangkan pertumbuhan dan sumbangannya dalam mengembangkan pemikiran dan kefahaman hadith dan ilmunya. Ia berusaha menjelaskan prinsip dan usul alsharh dan pemahaman terhadap manhaj yang digariskan dalam penghasilan kitab-kitab syarah. Perbincangan menfokuskan kepada manhaj dan ittijahat al-sharh dalam mengupas dan menafsirkan teks-teks hadith. Penelitian ini bersifat kualitatif dari jenis kajian pustaka yang berbentuk analisis teks. Sumber-sumber kajian diperoleh dari bahan-bahan primer dan sekunder berupa karya-karya hadith klasik dan penelitian-penelitian mutakhir tentang prinsip dan epistemologi syarah. Data kajian dianalisis secara deskriptif, komparatif dan analitis. Temuan kajian mendapati ilmu syarah telah berkembang dalam kajian dan penelitian hadith yang meluas yang digarap dalam karya-karya hadith klasik dan teks-teks syarahnya dalam kurun sejarah yang panjang. Konteks pemikiran syarah ini terus berkembang di abad mutakhir dengan penghasilan karya-karya syarah yang membawa kefahaman dan komentar-komentar hadith yang moden dan kontekstual.
\end{abstract}

Kata Kunci: ilmu syarah; usul al-sharh; ittijahat al-sharh.

\begin{abstract}
This paper discusses the development of science of hadith commentary since early century of Hijrah. It traces its historical development and instrumental role in expanding the dynamic understanding of hadith and its science. The paper attempts to illustrate the principle and discipline of usul al-sharh as set forth in the major works of hadith commentary underlying its principle, context and method. The discussion focusses on the method and approaches (ittijahat al-sharh) of traditionalist in interpreting and commenting the texts. The study is based on qualitative method in the form of library research, focusing on content analysis. The sources of documentation was primarily derived from traditional and classical works of hadith and contemporary references that provide extensive analysis of hadith commentary. The study found that the science of hadith commentary was originated in the classical and medieval hadith works that extensively articulated its rigorous and underlying principle. This
\end{abstract}

Rusydiah: Jurnal Pemikiran Islam, Vol. 2, No. 2, Desember 2021 
tradition was continued in modern context in the highly authoritative works of hadith commentary that brought forth modern and contextual approaches in analyzing hadith texts.

Keywords: science of hadith commentary; usul al-sharh; ittijahat al-sharh.

\section{PENDAHULUAN}

Ilmu syarah telah dibangunkan seawal abad ke-2 Hijrah dengan percambahan dan pemekaran kitab-kitab syarah yang tersebar luas di dunia Islam. Penulisan dan perbahasan teks hadith ini telah memberikan impak yang signifikan dalam mengangkat dan mengembangkan disiplin syarah yang kritis. Karya-karya ini mengemukakan analisis hadith yang meluas dengan penghuraian teks yang mengesankan dan diperkukuh dengan kekuatan dalil dan manhaj. ${ }^{1}$

Artikel ini berusaha membahaskan perkembangan ilmu syarah dan melihat latar pertumbuhan dan perkembangannya dalam sejarah. Ia memperhalusi metode penulisan kitab-kitab syarah yang dihasilkan sejak zaman klasik dan pertengahan, dan membandingkan kekuatan prinsip dan manhaj yang dilakarkan. Perbincangan diakhiri dengan kesimpulan ringkas tentang sumbangan penulisan syarah dalam mengembangkan tradisi pemikiran dan disiplin syarah, dan pengembangan pemikiran Islam dan melihat usaha-usaha pembaharuan yang dibawa dalam kajian hadith dan syarah kontemporer.

Dalam kajiannya tentang upaya meningkatkan visualisasi hadith, Siti Fadzilah et al. mencadangkan kaedah visualisasi maklumat syarah hadith sebagai satu cara penyajian ilmu syarah yang ilustratif dan inovatif. ${ }^{2}$ Terkait dengan metodologi syarah yang mencorakkan pemahaman hadith dalam tradisi keilmuan Islam klasik, Yunita Kurniati menggariskan upaya rekonstruksi dalam penelitian teks-teks hadith, dari penjelasan umum (ijmali) yang terkait dengan sejarah dan bahasa kepada penekanan terhadap metode multidisipliner yang berpengaruh dalam aliran dan tradisi keilmuan semasa. Kendatipun demikian, metode klasik menampilkan objektivas yang tinggi dalam pemaknaan hadith yang bisa diandalkan sebagai referensi klasik ketimbang metodologi mutakhir yang sangat

\footnotetext{
${ }^{1}$ Perbahasan tentang ilmu syarah disentuh secara ringkas dalam muqaddimah kitab Ibn Sayyid al-Nas, Muhammad al-Ya'mari, Al-Nafh al-Shadhi fi Sharh Jami' al-Tirmidhi, diedit oleh Ahmad Ma'bad 'Abd al-Karim (Riyad: Dar al-'Asimah, 1409 H), 1/91, dan Al-Mubarakfuri, Abu al-'Ala Muhammad 'Abd al-Rahman b. 'Abd alRahim, Tuhfat al-Ahwadhi bi Sharh Jami' al-Tirmidhi (Beirut: Dar al-Kutub al-'Ilmiyah, t.t.), 1/7.

2 Siti Fadzilah Mat Noor, Hairulliza Mohamad Judi, Noor Syafawati Rahim, 'Teknik Visualisasi Maklumat Syarah Hadis', Journal of Hadith Studies, 3.1 (2018), h. 19-35.
} 
jauh dari makna asli yang dikehendaki oleh nass kerana upaya menguatkan ideologi dan keyakinan kelompoknya. ${ }^{3}$

Manakala Akhmad Sagir dalam telaahnya terhadap perkembangan syarah menyorot perkembangan tradisi keilmuan dan evolusi penting dari pemikiran syarah dalam konteks sejarahnya. Pertumbuhannya agak terlambat berbanding cabang ilmu hadith yang lain, ini disebabkan disiplin syarah ini terangkum di dalamnya ilmu-ilmu yang terkait dengan hadith, seperti fiqh, usul, bahasa, nahu, sejarah dan lain-lain. Penelitiannya memberikan latar penting tentang landas dan konteks sejarah dalam pertumbuhan tradisi syarah dan konsep-konsep pokoknya yang fundamental. Ia turut mengkaji prinsip dan idealisme dan struktur asas yang dibangunkan dalam karya-karya syarah dan usulnya yang muktabar dan metode dasar yang dirumuskan dalam lembaran-lembaran teksnya yang awal. Kerangka pemikiran syarah yang dilontarkan ini berpengaruh dan punyai peranan yang instrumental terhadap perkembangan tradisi keilmuan hadith dan percambahan epistemologinya yang dikembangkan dalam pemikiran hadith dan tradisi intelektualnya. ${ }^{4}$ Dalam telaahnya terhadap metodologi syarah Ibn Hajar ke atas hadith dalam bab halawah al-iman dalam kitab Sahih al-Bukhari, Aan Supian menyorot tentang permasalahan pemahaman hadith-hadith Nabi SAW yang dimusykilkan sekian lama oleh pertentangan-pertentangan yang ditimbulkan oleh persoalan ini, di mana ia berpandangan harus melihat pada orientasi pemahaman Rasulullah SAW dan para sahabat di mana pemahamannya paling dekat dengan kehendak dan semangat syariat. ${ }^{5}$

\section{METODE}

Penelitian ini bersifat kualitatif dari jenis kajian pustaka yang berbentuk analisis teks. Sumber-sumber kajian diperoleh dari bahan-bahan primer dan sekunder berupa karya-karya hadith klasik dan penelitian-penelitian mutakhir tentang prinsip dan epistemologi syarah. Data diproses secara analitis, deduktif, historis dan komparatif bagi membuat kesimpulan dan penemuan akhir.

\footnotetext{
${ }^{3}$ Yunita Kurniati, 'Rekonstruksi Metodologi Keilmuan Syarah Hadis Klasik', Islam Transformatif: Journal of Islamic Studies, 4.1 (2020), 46-56.

4 Akhmad Sagir, 'Perkembangan Syarah Hadis dalam Tradisi Keilmuan Islam', Ilmu Ushuluddin, 9.2 (Juli 2010), 129-151.

${ }^{5}$ Aan Supian, 'Metode Syarah Fath al-Bari (Studi Syarah Hadis Pada Bab Halawah al-Iman)', Nuansa, X.1 (2017), 24-34.
} 


\section{HASIL DAN PEMBAHASAN}

Tema perbincangan yang digarap tentang latar sejarah dan perkembangan ilmu syarah ini merangkumi penelitian berikut:

1. Ta'rif ilmu syarah

2. Kepentingan ilmu syarah

3. Perkembangan dan kemajuan yang dicapai dalam penulisan syarah

4. Manhaj ‘Ulama dalam menggariskan kerangka syarah

5. Bentuk penulisan dan metodologi syarah

6. Sumbangan 'Ulama Islam di Maghribi, jazirah Arab, India, dan rantau nusantara dalam bidang syarah.

7. Kitab-kitab syarah hadith yang muktabar.

\section{Takrif Ilmu Syarah}

Syarah dari segi bahasa bermaksud menghuraikan sesuatu, memperluas dan melapangkannya. Firman Allah SWT:

"Maka sesiapa yang dikehendaki Allah untuk memperoleh petunjuk, nescaya dilapangkan dadanya untuk menerima Islam." [Al-An'am: 25]

Dan setiap yang dikupas dan dijelaskan dari suatu jawahir adalah penyingkapan dan penzahirannya 6 Dari segi istilah, ilmu syarah bermaksud:

"Menghuraikan lafaz hadith dan menjelaskan maknanya."7

Imam al-Qinnawji (1248-1307 H/1832-1890 M) menerangkan maksud ilmu syarah hadith:

"Ilmu yang mencari maksud hadith yang diungkapkan Rasulullah SAW, mengikut kaedah (bahasa) Arab, dan asas (usul) syari'at, dengan keluasan dan keupayaan manusia." ${ }^{8}$

${ }^{6}$ Al-Razi, Muhammad b. Abi Bakr, Mukhtar al-Sibhah (Beirut: Maktabah Lubnan, 1987), h. 354; Ibn Manzur, Abu al-Fadl Jamal al-Din Muhammad b. Mukarram, Lisan al-'Arab (Beirut: Dar Sadir, 1990), 2/497; Fayruz Abadi, Muhammad b. Ya'qub, Al-Qamus al-Mubit (Beirut: Mu’assasah al-Risalah, 1987), h. 289.

7 Al-Ashrafi, Hayfa' 'Abd al-'Aziz Sultani, 'Al-Sharh al-Mawdu'i li al-Hadith al-Sharif: Dirasah Nazariyah Tatbiqiyah’ (Tesis Sarjana, Kulliyyah Ilmu Wahyu dan Sains Kemanusiaan, Universiti Islam Antarabangsa Malaysia, 2007), h. 13.

8 Al-Qinnawji, Siddiq b. Hassan, Abjad al-Ulum al-Musamma bi al-Washy al-Marqum fi Bayan Ahwal al'Ulum, ed. oleh 'Abd al-Jabbar Zakkar (Beirut: Dar al-Kutub al-'Ilmiyah, 1999), 2/336, dinukil dari Al-Arniqi, 
Haji Khalifah menghuraikan pengertian ilmu syarah:

"Ilmu yang mengupas kefahaman lafaz al-hadith dan pengertiannya berdasarkan kaedah (bahasa) Arab dan kefahaman (nas) syariat dan selaras dengan latar keadaan (ahwal) Nabi SAW."9

\section{Kepentingan Ilmu Syarah}

Pengajian usul al-sharh melantarkan dasar yang signifikan dalam mengukuhkan kefahaman hadith dan fununnya. Ia menjadi landasan bagi ulama dalam merumus dan mentafsir dalil dan menggariskan kefahaman hukum dan kaedah istinbat. Antara kepentingan dan faedah yang dirangkul dari pengajian ilmu syarah termasuklah: (1) menjelaskan maksud dan kefahaman hadith (2) menghuraikan maqasid hukum dan nas (3) membandingkan manhaj dan pendekatan ulama dalam mentafsir dan mentakwil nas (4) menggariskan kaedah istinbat (5) Mengetahui faedah isnad dan kehalusan riwayat yang dikemukakan (6) merungkai kemusykilan pada lafaz hadith yang gharib dan mukhtalif (7) merangka manhaj perbahasan dan perbincangan yang berkesan dalam interpretasi nas. ${ }^{10}$

\section{Perkembangan Ilmu Syarah}

Perkembangan awal ilmu syarah dikesan sejak abad ke-2 Hijrah dengan penghasilan yang meluas kitab-kitab syarah yang tersebar di dunia Islam. Karyakarya ini merintis upaya awal dalam membahaskan maksud dan kefahaman hadith, yang dibarengi dengan prinsip dan usul syarah yang jelas. Usul al-sharh merupakan disiplin yang terpenting dalam ilmu hadith al-dirayah. ${ }^{11}$ Ia

Muhammad b. Qutb al-Din al-Rumi, Madinat al-Ulum (Beirut: Dar al-Kutub al-'Ilmiyah, 1978), h. 140; Harbi, Ibrahim b. Ishaq, Gharib al-Hadith, diedit oleh Sulayman b. Ibrahim b. Muhammad al-'Ayid (Jeddah: Dar alMadani, 1985), 1/290; Ibn Sidah, 'Ali ibn Isma'il, Al-Mukhassas (Beirut: Maktabah al-Tijariyah li al-Tiba'ah wa alNashr, 1965), 2/37; Jawhari, Isma'il ibn Hammad, Taj al-Lughah wa Sihah al-'Arabiyah, ed. oleh 'Abd al-Ghafur 'Attar (Riyad: Shabatli, 1982), 1/337.

${ }^{9}$ Hajji Khalifah, Mustafa ibn 'Abd Allah, Kashf al-Zunun 'an Asami al-Kutub wa al-Funun (Beirut: Dar alFikr, 1990), 2/1036.

10 Fath al-Din Bayanuni, 'Ahammiyah al-Shuruh al-Hadith wa Qawa'iduha', Mu'tamar 'Alami 'an Manahij Tafsir al-Qur'an al-Karim wa Sharh al-Hadith al-Sharif, 2/945-976, Humayd, Ahmad b. Muhammad, 'Ilm Sharh al-Hadith wa Marahilihi al-Tarikhiyah Bayna al-Taq'id wa al-Tatbiq', Mu'tamar 'Alami, h. 1206.

${ }^{11} \mathrm{Ilmu}$ syarah hadith mencakup perbahasan ilmu dirayah al-hadith, ilmu dirayah al-sanad dan ilmu dirayah almatan. Haji Khalifah (Katib Chalabi) menyatakan: "Ilmu syarah hadith terangkum dalam cabang juzuk furu' albadith". Haji Khalifah, Kashf al-Zunun, op.cit., 2/1036, Ibn al-Akfani, Abi 'Abdullah Muhammad b. Sa'id al-Ansari, Irshad al-Qasid ila Asna al-Maqasid (Jeddah: Dar al-Qiblah li al-Thaqafah al-Islamiyah, 1994), h. 107, Tashkubra 
menggariskan manhaj perbahasan kitab-kitab sharh hadith. Kupasan isnad dan matan dan penelitian teks yang mendalam telah menyumbang dalam membangunkan disiplin syarah yang kritis dalam memahami nas.

Usaha penafsiran dan pentakwilan al-hadith telah berkembang seawal kurun pertama Hijrah dengan tafsiran Rasulullah SAW sendiri terhadap lafaz dan ibarat hadith yang musykil. Para Sahabat (rad) dan Tabi'in (rah) yang lahir pada kurun ini turut menyumbang dalam usaha menafsir dan mensyarah hadith seperti yang dilakukan oleh 'Abdullah ibn Mas'ud, 'Abdullah ibn 'Abbas, 'Ali b. Abi Talib, 'A'ishah binti Abi Bakr (614-678 M), para Ummahat al-Mu'minin (rad), ${ }^{12}$ 'Ikrimah mawla Ibn Abbas, Mujahid, 'Ata', Hasan al-Basri, Sa'id b. Jubayr, Muhammad b. Muslim al-Zuhri, Yahya b. Sa'id al-Ansari, Sufyan b. 'Uyaynah, Hisan b. 'Aliyah (rah) (w. $130 \mathrm{H}$ ) dan sebagainya. Pandangan dan ijtihad Sahabat (rad) dirujuk dalam merungkai dan menjelaskan kekhilafan nas syarak. Fatwa yang dikemukakan turut diangkat sebagai sandaran dan patokan hukum yang muktamad. 13

Perbahasan hadith yang meluas telah dipelopori oleh ulama-ulama di Maghrib dengan penghasilan karya syarah yang signifikan terhadap kitab alMuwatta' karya Imam Malik (rah) (w. 179 H). ${ }^{14}$ Ini diperkukuh dengan penulisan

Zadah, Ahmad b. Mustafa, Miftah al-Sa'adah wa Misbah al-Siyadah fi Mawdu'at al-'Ulum, diedit oleh Kamil Bakri, 'Abd al-Wahab Abu al-Nur (Mesir: Dar al-Kutub al-Hadithah, t.t.), 2/377, Al-Qinnawji, Abjad al-'Ulum, 2/6.

${ }^{12}$ Di zaman Khalifah al-Rashidun, terdapat 27 orang Sahabat (rad) yang diangkat sebagai ahli hukum dan fatwa. Ulama telah membahagikan mereka kepada 2 kumpulan mengikut pencapaian dan kefahamannya dalam fiqh, 7 orang Sahabat (rad) yang termasuk dalam kategori pertama ialah: 'Umar ibn al-Khattab, 'Ali ibn Abi Talib, 'A'ishah binti Abi Bakr, 'Abdullah ibn Mas'ud, Zayd b. Thabit, 'Abdullah ibn 'Abbas dan 'Abdullah ibn 'Umar (rad). Manakala dalam kategori kedua ialah: Abu Bakr al-Siddiq, Umm Salamah, Anas ibn Malik, Abu Sa'id alKhudriy, Abu Musa al-Ash'ari, Sa'ad ibn Abi Waqqas, Abu Hurairah, 'Uthman ibn 'Affan, 'Abdullah ibn 'Amr, 'Abdullah ibn al-Zubayr, Salman al-Farisi, Jabir ibn 'Abdullah, Mu'adh ibn Jabal, Talhah b. 'Ubaydillah, Zubayr ibn al-'Awwam, 'Abd al-Rahman ibn 'Awf, 'Imran ibn Husayn, Abu Bakrah, 'Ubadah ibn al-Samit dan Mu'awiyah ibn Abi Sufyan (rad). Isma'il Raji al-Faruqi \& Lois Lamya’ al-Faruqi, The Cultural Atlas of Islam (New York: Macmillan Publishing, 1986), h. 274.

13 Syarahan hadith digerakkan secara syafahiyah dengan perantaraan lisan. Pandangan Sahabat (rad) dirujuk bagi menjelaskan ahwal al-Nabi (saw) dan menghuraikan asbab al-wurud. A. Hasan Asy'ari, 'Sejarah dan Tipologi Syarah Hadis', Jurnal Teologia, 19.2 (2008), 340-362; Farhad Daftary, 'Intellectual Traditions in Islam', dalam Norman Calder, The Limits of Islamic Orthodoxy (London: Taurus, 2000), h. 75; Fath al-Din Bayanuni, 'Ahammiyah al-Shuruh al-Hadith wa Qawa'iduha', Mu’tamar 'Alami, h. 956.

${ }^{14}$ Kitab syarah hadith yang terawal dihasilkan ialah Sharh al-Muwatta' karya Abu Muhammad 'Abdullah b. Nafi' al-ma'ruf bi ibn al-Sa'ig (w. 186 H), 'Abdullah b. Wahb (w. 197 H), 'Isa b. Dinar (w. 232 H), dan 'Abd alMalik b. Habib b. Sulayman al-Maliki al-Qurtubi (w. 239 H). Qadi 'Tyad menyebut: "Tiada suatu kitab dalam ilmu hadith yang dikerahkan inayah oleh 'Ulama (dalam mensyarahnya) seperti kitab al-Muwatta'. Al-Yahsubi, 'Iyad b. Musa, Tartib al-Madarik wa Taqrib al-Masalik li Ma'rifat A 'lam Madhbab Malik (Ribat: Wizarat al-Awqaf wa al-Shu'un al-Islamiyah, 1967), 1/198; Al-Dhahabi, Shams al-Din Muhammad b. Ahmad b. 'Uthman, Siyar A 'lam al-Nubala' (Beirut: Mu'assasah al-Risalah, 1992), 8/86. 
dan perbincangan yang substantif terhadap hadith-hadith gharib, ${ }^{15}$ mushkil dan mukhtalaf. Karya-karya ini menzahirkan manhaj yang kritis dalam perbahasan hadith dan mengetengahkan kefahaman hukum dan perincian fatwa dan nas yang tuntas dan mengesankan. Ia menggariskan kerangka besar pemikiran syarah dengan upaya penggarapan hadith (figh al-hadith) dan pentarjihan yang kental, yang melantarkan asas kepada pengembangan ilmu syarah dan penelitian hadith yang dinamik dan tuntas. Ini termasuklah kitab:

1. Gharib al-Muwatta' oleh 'Abdullah b. Wahb al-Misri (w. 197 H).

2. Ikhtilaf al-Hadith oleh Imam Abu 'Abdullah Muhammad b. Idris al-Shafi'i (w. $820 \mathrm{M}$ ).

3. Gharib al-Hadith wa al-Athar oleh Abu 'Ubayd al-Qasim b. Sallam (w. 224 $\mathrm{H} / 837 \mathrm{M})$.

4. Gharib al-Hadith dan Ta'wil Mukhtalif al-al-Hadith oleh Abu Muhammad 'Abdullah ibn Muslim ibn Qutaybah al-Dinawari al-Marwazi (213-276 $\mathrm{H} / 828-889 \mathrm{M})$.

5. Gharib al-Hadith oleh Abu Ishaq Ibrahim b. Ishaq al-Harbi (w. $285 \mathrm{H})$.

6. Tahdhib al-Athar wa Tafsil al-Thabit 'an Rasul Allah (saw) min al-Akhbar oleh Abu Ja'far Muhammad ibn Jarir al-Tabari (w. 310 H/838-923 M). ${ }^{16}$

7. Sharh Mushkil al-Athar oleh Abu Ja'far Ahmad b. Muhammad b. Salamah b. 'Abd al-Malik b. Salamah al-Tahawi (w. 935 M).

8. Gharib al-Hadith oleh Abu Sulayman Hamd b. Muhammad b. Ibrahim alKhattabi al-Busti (931-996 M).

9. Mushkil al-Hadith wa Bayanuh oleh Abu Bakr Muhammad ibn al-Hasan ibn Furak al-Asbahani (330-406/941-1015).

10. Al-Gharibayn fi al-Qur'an wa al-Hadith oleh Abu 'Ubayd Ahmad b. Muhammad al-Hirawi (w. $410 \mathrm{H}$ ).

11. Al-Fa'iq fi Gharib al-Hadith oleh Abu al-Qasim Mahmud ibn 'Umar alZamakhshari (w. 538 H/1075-1144 M).

12. Gharib al-Hadith dan Al-Tahqiq fi Masa'il al-Khilaf oleh Abu al-Faraj ‘Abd al-Rahman ibn ‘Ali ibn Muhammad ibn al-Jawzi (508-597 H).

\footnotetext{
${ }^{15}$ Dr. Ahmad b. 'Abd al-Qadir 'Azzi menyebut: "Dan tidak syak bahawa karya dalam gharib al-hadith merupakan asas yang membina syarahnya, dan menyempurnakan langkah ke arah mencapai maknanya." "Azzi, Ahmad b. 'Abd al-Qadir, h. 926. Shaykh Ahmad al-Shirqawi mengesan lebih 70 buah kitab gharib al-hadith yang dihasilkan oleh Ulama hadith. Ahmad al-Shirqawi, Iqbal, Mu'jam al-Ma'ajim (Beirut: Dar al-Gharb al-Islami, 1407 H), h. 23.

16 Al-Haddad, h. 567.
} 
13. Al-Nihayah fi Gharib al-Hadith wa al-Athar oleh Abi al-Sa'adat Majd al-Din al-Mubarak b. Muhammad ibn al-Athir al-Jazri (w. 606 H/1149-1209 M).

14. Mukhtasar fi Gharib al-Hadith oleh Muwaffaq al-Din Abu Muhammad 'Abd Allah b. Ahmad b. Muhammad ibn Qudamah al-Hanbali alMaqdisi (541-629 H). ${ }^{17}$

Gerakan syarah terus diperluas dengan usaha pencarian dan pembukuan hadith yang kritis. Pertentangan antara mazhab Ahl al-Kalam dan Ahl al-Hadith telah melahirkan kitab yang merungkai ikhtilaf dan pertentangan hadith muyskil seperti Ta'wil Mukhtalif al-Hadith oleh Ibn Qutaybah al-Dinawari. Kurun ini juga menyaksikan pertumbuhan kitab-kitab musnad seperti Musnad 'Ubayd Allah ibn Musa (w. 213 H) dan Musnad al-Humaydi (w. 219 H) dan kitab-kitab Sahih, Sunan dan Musannaf seperti Sahih al-Bukhari (w. 256 H), Sahih Muslim (w. 261 H), Musannaf 'Abd al-Razzaq al-San'ani (w. 211 H) dan Musannaf Ibn Abi Syaibah (w. 235 H). ${ }^{18}$

Kurun keempat menyerlahkan dimensi baru dalam penulisan hadith dengan terhasilnya kitab-kitab hadith al-Masanid dan al-Jami' yang komprehensif. Para ulama hadith yang masyhur turut menyumbangkan upaya yang keras dalam penghasilan kitab syarah seperti kitab I'lam al-Sunan ${ }^{19}$ dan Ma'alim al-Sunan ${ }^{20}$ oleh Imam Abu Sulayman al-Khattabi Hamd b. Muhammad al-Busti (w. 388 H), alAmthal min al-Kitab wa al-Sunnah oleh Abu 'Abdullah Muhammad b. 'Ali al-Hakim al-Tirmidhi (w. $320 \mathrm{H}$ ) dan Ma'ani al-Akhbar wa Sharh al-Athar oleh Abu Bakr Muhammad b. Ishaq al-Kalabadhi (w. 384 H). ${ }^{21}$

Kurun kelima turut melahirkan ulama-ulama besar dari Maghrib yang menyempurnakan syarahan terbaik terhadap kitab al-Muwatta' seperti kitab al-

\footnotetext{
${ }^{17}$ Antara Ulama-Ulama hadith yang masyhur dengan penulisan gharib al-hadith termasuklah Imam Abu 'Adnan 'Abd al-Rahman b. 'Abd al-A'la al-Sulami, dari kalangan ahli kurun kedua Hijrah, kemudian al-Nadr b. Shamil al-Mazini (w. 204 H), Muhammad b. al Mustanir yang digelar sebagai Qutrab (w. 206 H), Abu 'Ubaydah Ma'mar b. al-Muthanna (w. 209 H), 'Abd al-Malik b. Qurayb al-'Asma'i (w. 216 H), Abu 'Ubayd al-Qasim b. Sallam (w. $224 \mathrm{H}$ ) yang menghimpunkan kitabnya 'Gharib al-Hadith wa al-Athar' selama 40 tahun, Abu Muhammad 'Abd Allah b. Muslim b. Qutaybah al-Dinawari dan Abu Sulayman al-Khattabi. Ibn al-Athir, Majd al-Din alMubarak ibn Muhammad, Al-Shafi fi Sharh Musnad al-Shafi T, ed. oleh Ahmad b. Sulayman dan Abi Tamim Yasir b. Ibrahim (Riyad: Maktabat al-Rushd, 2005), 1/46, Al-Suyuti, Tadrib al-Rawi fi Sharh Taqrib al-Nawawi, 2/184, Haji Khalifah, Kashf al-Zunun, 2/1718, 'Azzi, Ahmad b. 'Abd al-Qadir, h. 927, Khayr Abadi, Muhammad Abu al-Layth, 'Ulum al-Hadith Asiluha wa Mu'asiruba. Cet. 4 (Selangor: Dar al-Shakir, 2004), h. 323-4.

18 Al-Ashrafi, Hayfa', h. 33, Humayd, Ahmad b. Muhammad, 'Ilm Sharh al-Hadith wa Marahilihi alTarikhiyah Bayna al-Taq'id wa al-Tatbiq', Mu’tamar 'Alami, h. 1215.

${ }^{19}$ Syarahan ringkas kitab Sabih al-Bukhari.

${ }^{20}$ Syarah kitab Sunan Abu Dawud dari riwayat Ibn Dasah. 'Azzi, 'Manahij al-Muhaddithin fi Shuruh alHadith, Mu'tamar 'Alami', h. 926.

${ }^{21}$ Humayd, Ahmad b. Muhammad, 'Ilm Sharh al-Hadith wa Marahilihi al-Tarikhiyah Bayna al-Taq'id wa al-Tatbiq', Mu’tamar 'Alami), h. 1219.
} 
Tamhid lima fi al-Muwatta' min al-Ma'ani wa al-Asanid,22 dan al-Istidhkar23 oleh Abu 'Umar Yusuf b. 'Abd Allah b. Muhammad b. 'Abd al-Bar al-Namari al-Qurtubi (w. $463 \mathrm{H})$, Al-Istifa' fi Sharh al-Muwatta' oleh Abu al-Walid Sulayman b. Khalaf al-Baji (w. 474 H) dan Sharh Sahih al-Bukhari, oleh Abu al-Hassan 'Ali b. Khalaf b. Battal alMaghribi al-Maliki (w. 449 H). Ia turut melakarkan pencapaian dalam penulisan kitab-kitab hadith klasik dan perbahasan hadith al-Sahihayn seperti kitab al-Jam' bayna al-Sahihayn oleh Ibn al-Furat (w. $414 \mathrm{H})$ dan Tafsir Gharib ma fi al-Sahihayn oleh Muhammad b. Nasr al-Humaydi al-Andalusi (w. 488 H).

Kurun keenam Hijrah menimbulkan upaya penting dalam tradisi syarah di mana ia merupakan abad penelitian dan pengumpulan hadith yang klasik. Ia turut melahirkan karya-karya besar dalam ilmu hadith dan penulisan syarah yang kritis seperti kitab Sharh al-Sunnah oleh Imam Husayn b. Mas'ud al-Baghawi (w. 516 H), al-Muqtabis oleh al-Bathalyusi (444-521 H), ${ }^{24}$ Kashf al-Mushkil 'ala Sahih al-Bukhari oleh Abu al-Faraj 'Abd al-Rahman ibn 'Ali ibn al-Jawzi (510-597 H), Al-Mu'lim bi Fawa'id Kitab Muslim oleh Abi 'Abdillah Muhammad b. 'Ali al-Maziri (w. $536 \mathrm{H}$ ) dan Al-Muyassar oleh Shihab al-Din Fadl Allah b. Husayn al-Turbishti (w. 600 H). ${ }^{25}$

Kajian syarah terus diperluas dengan munculnya Ulama-Ulama hadith di abad ketujuh yang mencatatkan pengaruh penting dalam pengetahuan hadith dan syarah dengan penulisan dan penelitian teks-teks hadith yang substantif. Ia menzahirkan kupasan dan perbahasan terperinci dengan kekuatan dan ketinggian manhaj yang dilakarkan seperti kitab al-Minhaj fi Sharh Sahih Muslim al-Hajjaj oleh Imam Abu Zakariya Yahya b. Sharaf al-Nawawi (w. 676 H), Al-Shafi fi Sharh Musnad al-Shafi'i oleh Abu al-Sa'adat al-Mubarak b. Muhammad b. 'Abd al-Karim ibn al-Athir al-Shaybani al-Jazri (w. $606 \mathrm{H})$, Mushkilat al-Bukhari oleh Abu 'Amru ibn al-Salah (w. $643 \mathrm{H}$ ) Sharh al-Muwatta' oleh Abu al-Majdi ‘Uqayli b. 'Atiyyah alQuda'i (w. 608 H) dan Bahjat al-Nufus Sharh Mukhtasar Sahih al-Bukhari al-musamma Jam' al-Nihayah fi Bad' al-Khayr wa al-Ghayah oleh Abu Muhammad 'Abd Allah b. Abi Jamrah al-Andalusi (w. 699 H).

Kurun kelapan Hijrah merupakan antara abad yang terbaik yang melahirkan karya-karya besar yang mengupas dan membahaskan Kutub Hadith alSittah seperti kitab Fath al-Bari bi Sharh al-Bukhari oleh Zayn al-Din 'Abd al-Rahman ibn Ahmad ibn Rajab al-Hanbali (736-795 H), Al-Mafatih fi Hil al-Masabih oleh

\footnotetext{
${ }^{22}$ Kitab yang disusun mengikut nama Shuyukh Imam Malik.

${ }^{23}$ Kitab yang dikelaskan mengikut bab fiqh, dengan mengetengahkan pendapat fuqaha' dan muhaddith.

${ }^{24}$ Al-Kandahlawi, Muhammad Zakariya, Awjaz al-Masalik ila Muwatta' Malik (Beirut: Dar al-Fikr, t.t.), h. 45-55.

${ }^{25}$ Syarah kitab Masabih al-Sunnah karya Imam al-Baghawi (w. 516 H). Al-Ashrafi, Hayfa', h. 35.
} 
Mazhar al-Din al-Husayn b. Mahmud b. al-Hassan al-Zaydani (w. $727 \mathrm{H}), A l-$ Kawakib al-Darari oleh Shams al-Din Muhammad ibn Yusuf al-Kirmani (w. 786 H), Taysir al-Maram fi Sharh 'Umdat al-Ahkam oleh Muhammad b. Ahmad b. Marzuq alTilimsani al-Maliki (w. $781 \mathrm{H}$ ), Al-Talwih bi Sharh al-Jami' al-Sahih oleh Abu 'Abdullah 'Ala' al-Din Mughlatay al-Bakjari al-Hakri al-Hanafi (689-762 H), Kashf al-Ghita' fi Sharh Mukhtasar al-Muwatta' oleh Abu Muhammad b. Abi al-Qasim alFarhuni al-Ya'muri al-Tunisi (w. 763 H), Shawahid al-Tawdih fi Sharh al-Jami' al-Sahih oleh Siraj al-Din Abi Hafs 'Umar b. 'Ali b. al-Mulaqqin al-ma'ruf bi Ibn al-Nahwi (723-804 H) dan Al-Tanqih li Alfaz al-Jami' al-Sahih oleh Badr al-Din Muhammad b. Bahadur al-Zarkashi (w. $794 \mathrm{H}$ ).

Kurun kesembilan Hijrah merupakan kemuncak dari ilmu syarah dengan terhasilnya karya-karya syarah yang teragung seperti kitab Fath al-Bari bi Sharh Sahih al-Bukhari oleh Ahmad b. 'Ali b. Hajar al-'Asqalani (773-852 H), 'Umdat alQari dan Mabani al-Akhbar fi Sharh Ma'ani al-Athar oleh Badr al-Din Abi Muhammad Mahmud ibn Ahmad al-'Ayni (762-855 H), Sharh Zawa'id al-Mujtaba 'ala al-Arba'ah dan Sharh Zawa'id Sunan al-Tirmidhi 'ala al-Sahihayn wa Abi Dawud oleh Siraj al-Din 'Umar b. 'Ali b. al-Mulaqqin (w. $804 \mathrm{H}$ ) dan Al-Tawdih li Mubhamat al-Jami' al-Sahih oleh Muwaffaq al-Din Abi Dhar Ahmad b. Ibrahim b. Muhammad b. Khalil al-Tarabilisi al-Halabi al-shahir bi Sibt Ibn al-'Ajami (w. 884 H). ${ }^{26}$

Kurun kesepuluh Hijrah menyerlahkan hasil penyorotan berbentuk hashiyah yang ringkas seperti yang diusahakan oleh Imam Jalal al-Din al-Suyuti (849-911 H) yang mensyarah keseluruhan Kutub Hadith al-Sittah. ${ }^{27}$ Ulama-Ulama lain turut menghasilkan karya syarah dan hashiyah yang mendasar seperti Muhammad ibn 'Abd al-Rahman al-Sakhawi (831-902 H/1428-1497 M), Shams al-Din Muhammad b. al-'Alqami al-Shafi'i (w. 929 H), ${ }^{28}$ Abi al-'Abbas Shihab al-Din Ahmad ibn Muhammad al-Qastalani (851-923 H), ${ }^{29}$ Zayn al-Din 'Abd al-Rahim b. 'Abd alRahman b. Ahmad al-'Abbasi al-Shafi'i 30 dan Shaykh al-Islam Abu Yahya Zakariya b. Muhammad al-Ansari (w. 926 H). ${ }^{31}$

\footnotetext{
${ }^{26}$ Keunggulan kurun ini diserlahkan dengan lahirnya kitab Sharh al-Zawa'id dan Sharh ke atas Kutub Shuruh al-Hadith. Al-Ashrafi, Hayfa' 'Abd al-'Aziz Sultani, h. 37.

27 Seperti kitab Al-Tawshih 'ala al-Jami' al-Sahih.

28 Penyusun kitab Sharh al-Jami' al-Saghir min Hadith al-Bashir al-Nadhir (saw) karya Imam al-Suyuti.

29 Penulis kitab Irshad al-Sari li Sharh Sabih al-Bukhari.

${ }^{30}$ Penyusun kitab Sharh al-Jami' al-Sabih.

31 Penulis kitab Tubfat al-Bari bi Sharh Sabih al-Bukhari dan Fath al-'Allam bi Sharh al-Ilam bi Ahadith alAbkam.
} 
Kurun kesebelas Hijrah mengetengahkan karya dan penulisan syarah yang ringkas, menyambung upaya komentar terdahulu seperti kitab Taysir al-Qari' fi Sharh Sahih al-Bukhari oleh Nur al-Haq 'Abd al-Haq al-Bukhari (w. $1073 \mathrm{H}), 32$ Hashiyat 'Awn al-Ma'bud oleh Mawlawi Wahid al-Zaman, ${ }^{33}$ Fayd al-Qadir Sharh alJami' al-Saghir oleh 'Abd al-Ra'uf al-Munawi al-Shafi'i (w. $1031 \mathrm{H}$ ) dan Mirqat alMafatih Sharh Mishkat al-Masabih oleh Mulla 'Ali al-Qari (w. 1014 H).

Kurun kedua belas Hijrah menampilkan aliran baru dalam penelitian hadith dan perbahasan hukum hadith dalam bentuk penghasilan sederhana dan pertengahan (tawassut) seperti yang dikemukakan dalam kitab Subul al-Salam Sharh Bulugh al-Maram oleh al-Amir al-San'ani (1099-1182 H), Al-Musawwa Sharh alMuwatta' oleh Shah Waliyullah b. 'Abd al-Rahim al-Dehlawi (w. 1176 H), Sharh alZurqani 'ala al-Muwatta' oleh Muhammad b. 'Abd al-Baqi b. Yusuf al-Zarqani alMisri al-Azhari al-Maliki (w. 1122 H/1645-1710 M) dan Mukhtasar Fath al-Bari oleh Imam Muhammad ibn 'Abd al-Wahab al-Tamimi (1115-1206 H/1703-1792 M).

Kurun ketiga belas Hijrah merupakan dekad terpenting yang menyaksikan lahirnya kitab-kitab syarah yang terkemuka yang menyambung aliran dan tradisi mazhab klasik seperti al-Muhalla bi Asrar al-Muwatta' oleh Salam Allah al-Hanafi (w. 1229 H), Nayl al-Awtar min Ahadith Sayyid al-Akhyar (saw) Sharh Muntaqa alAkhbar oleh Muhammad b. 'Ali b. Muhammad al-Shawkani (1172-1255 H) dan Zubdat al-Fara'id wa Nazm al-La'i fi Sharh Thulathiyat al-Bukhari oleh Shaykh 'Abd alBasit al-Qanuji (w. $1223 \mathrm{H}$ ).

Kurun keempat belas Hijrah menyaksikan kelahiran ulama hadith dari India yang melakarkan pengaruh terbesar dalam bidang syarah. Ini dizahirkan dengan penghasilan meluas dalam penulisan syarah seperti kitab 'Awn al-Ma'bud Sharh Sunan Abi Dawud oleh 'Azim Abadi (w. 1329 H), Badhl al-Majhud Sharh Sunan Abi Dawud oleh Khalil Ahmad Saharanfuri (1269-1346 H), Tuhfat al-Ahwadhi bi Sharh Jami' al-Tirmidhi oleh Abu 'Ali Muhammad 'Abd al-Rahman b. 'Abd alRahim al-Mubarakfuri (1283-1353 H), Kawthar al-Ma'ani al-Dirari fi Kashf Khabaya Sahih al-Bukhari oleh Muhammad al-Khadri al-Jakni al-Shanqiti (w. 1353 M), Fath al-Mulhim li Sharh Sahih Muslim dan Fadl al-Bari Sharh Sahih al-Bukhari oleh Shabbir Ahmad al-'Uthmani al-Deobandi (w. 1369 H), Amani al-Ahbar fi Sharh Ma'ani alAthar oleh Muhammad Yusuf b. Muhammad Ilyas al-Kandahlawi (w. $1384 \mathrm{H}$ ), alTa'liq al-Sabih 'ala Mishkat al-Masabih oleh Muhammad Idris b. Muhammad Isma'il

\footnotetext{
${ }^{32}$ Kitab syarah yang dihasilkan dalam bahasa Parsi. Ashrafi, Haifa', h. 40.

${ }^{33}$ Fu'ad Sezkin, Tarikh al-Turath al-'Arabi, terj. oleh Mahmud Fahmi Hijazi, Fahmi Abu al-Fadl (Kaherah: al-Hay'ah al-Misriyah al-'Ammah li al-Kitab, 1977), 1/190.
} 
al-Kandahlawi (1312-1394 H/1974 M) dan Khasa'il al-Nabawi (saw) sharh Shama'il alTirmidhi oleh Mawlana Muhammad Zakariya b. Muhammad Yahya al-Kandahlawi al-Madani (1315-1402 H). ${ }^{34}$

Syarahan hadith di kurun kelima belas terus mekar dengan kelahiran kitabkitab syarah yang terunggul seperti Al-Mufahhim 'ala Mukhtasar Sahih Muslim oleh Dr. 'Abdullah b. 'A'id b. 'A'id Ali Majdu' al-Qarni, Fath al-Mun'im sharh Sahih Muslim oleh Prof. Dr. Musa Shahin Lashin, Qurrat 'Ayn al-Muhtaj Sharh Muqaddimah Muslim b. al-Hajjaj oleh Shaykh Muhammad b. 'Ali b. Adam alIthyubi, Kawkab al-Wahhaj wa Rawd al-Bahhaj fi Sharh Sahih Muslim al-Hajjaj oleh Muhammad Amin al-Harari, al-Ta'liq al-Raghib 'ala al-Targhib wa'l-Tarhib oleh Shaykh Muhammad Nasir al-din al-Albani (1333-1420 H) dan Al-Jami' fi Sharh alArba'in al-Nawawiyah oleh Abi 'Abdullah Muhammad Yusri. ${ }^{35}$

Terdapat juga pembaharuan yang diketengahkan dalam syarahan hadith di abad mutakhir seperti penzahiran teori al-i'jaz al-'ilm dalam al-hadith, 36 penyingkapan penemuan sains yang diungkapkan dalam hadith, ${ }^{37}$ syarahan dengan uslub al-jami' yang ringkas yang merangkumkan makna hadith yang syumul dan menyeluruh, dan sebagainya. ${ }^{38}$

\section{Manhaj Syarah 39}

Ulama-Ulama hadith telah menggariskan beberapa manhaj dalam menyorot dan mengupas kitab-kitab hadith yang muktabar. Antara kaedah dan pendekatan yang diketengahkan termasuklah:

${ }^{34}$ Kitab yang dihasilkan dalam tulisan urdu. Al-Khayr Abadi, Muhammad Abu al-Layth, 'Sharh alAhadith al-Nabawiyah (saw): Ta'sis wa Tatbiq', Mu'tamar 'Alami, h. 1301, Muhy al-Din 'Atiyah et.al., Dalil Mu'allafat al-Hadith al-Sharif: al-Matbu'at al-Qadimah wa'l-Hadithah, cet. 2 (Beirut: Dar Ibn Hazm, 1998), h. 277.

35 Para Ulama merumuskan bahawa kitab hadith yang paling banyak dibincangkan ialah Sabih al-Bukhari, diikuti al-Muwatta', Sabih Muslim, Sunan Abi Dawud, Sunan al-Tirmidbi, Sunan al-Nasa'i dan Sunan Ibn Majah. Terdapat juga kupasan terhadap kitab-kitab hadith yang lain seperti Masabih al-Sunnab karya Imam al-Baghawi, Mishkat alMasabib oleh Khatib al-Tibrizi, dan kitab-kitab hadith hukum seperti 'Umdat al-Abkam oleh 'Abd al-Ghani alMaqdisi, dan Bulugh al-Maram oleh al-Hafiz Ibn Hajar al-'Asqalani. 'Azzi, Ahmad b. 'Abd al-Qadir, h. 927.

36 Seperti yang dikemukakan dalam kitab al-I'jaz al-Tlmi fi al-Sunnah al-Nabawiyah (saw) oleh Dr. Salih b. Ahmad Rida dan al-Taswir al-Fanni fi al-Hadith al-Sharif oleh Muhammad Lutfi al-Sibagh.

${ }^{37}$ Seperti yang dibincangkan dalam kitab al-Isabah fi Sibhah al-Dhubabah oleh Dr. Khalil Mulla Khatir.

${ }_{38}$ Manzur, Muhammad Muhammad Ramadan, 'Al-Manahij al-Tajdidiyah fi Tafsir al-Qur'an al-Karim wa Shuruh al-Hadith al-Sharif, Mu'tamar Alami, h. 878.

${ }^{39}$ Manhaj dari segi bahasa bermaksud haluan dan alur yang jelas, dan pada istilah bermakna pendekatan yang diambil oleh para Mubaddithin untuk menghuraikan hadith. Ibn Sidah, 'Ali ibn Isma'il, Al-Mubkam wa al-Mubit al-A'zam fi al-Lughah, ed. oleh Mustafa al-Saqqa, Husayn Nassar (Mesir: Ma'had al-Makhtutat bi Jami 'at al-Duwal al-'Arabiyah, 1999), 4/171. 
1. Manhaj al-figh, yang menzahirkan kefahaman hukum dan menyingkapkan maqasid al-fiqh dan usul. ${ }^{40}$

2. Manhaj al-'aqidah, yang menekankan perbahasan kalam dan i'tiqad dan menyorot pandangan dan hujah dan argumentasi Ulama salaf. ${ }^{41}$

3. Manhaj al-tarjih, yang menggariskan kaedah tarjih dan perbandingan dalil dalam perbahasan hadith. Ia menekankan upaya pentarjihan hukum bersandarkan hujah mazhab yang terkuat. ${ }^{42}$

4. Manhaj al-tawfiq, yang menggarap dan merumuskan pandangan dan riwayat yang mukhtalaf dan merungkai percanggahan dalil dan ikhtilaf nas. ${ }^{43}$

Manhaj yang lain termasuklah huraian isnad secara khusus tanpa membahaskan matan dan penelitian riwayat dan lafaz hadith tanpa perbahasan nas yang lain. ${ }^{4}$

\section{Bentuk Syarah}

Kitab-kitab syarah yang dihasilkan terangkum dalam tiga bentuk:

1. Al-Mabsut, syarahan hadith dengan perbahasan yang meluas dan substantif terhadap nas. ${ }^{45}$

2. Al-Tawassut, syarahan hadith yang menampilkan manhaj yang pertengahan, dalam rangka perbahasan yang seimbang. ${ }^{46}$

${ }^{40}$ Ia terbahagi kepada Manhaj al-Figh al-Muqarin dan Manhaj al-Fiqh al-Madhbabi. Al-'Ani, 'Umar 'Abd al'Aziz, Adwa' 'ala al-Manhaj al-Fiqhi fi Sharh al-Hadith', Mu'tamar 'Alami 'an Manahij Tafsir al-Qur'an al-Karim wa Sharh al-Hadith al-Sharif, 2007), 3/1231-1264, Al-Faydi, Muhammad Bashar, Al-Ittijah al-Fiqhi lada Shurrah alHadith (Baghdad: Kulliyyah al-Shari'ah, Jami'ah Baghdad,1989), h. 255.

${ }^{41}$ Kandu, Muhammad Ishaq, Manhaj al-Hafiz Ibn Hajar al-'Asqalani fi al-'Aqidah: Risalah 'Tmiyah (Riyad: Maktabah al-Rushd, 1998), h. 15.

${ }^{42}$ Hayfa' 'Abd al-'Aziz., h. 58.

43 Bayanuni, h. 968.

${ }^{44}$ Khayr Abadi, Muhammad Abu al-Layth, 'Sharh al-Ahadith al-Nabawiyah (saw): Ta'sis wa Tatbiq', Mu'tamar 'Alami 'an Manahij Tafsir al-Qur'an al-Karim wa Sharh al-Hadith al-Sharif, op.cit., hal. 1301, Ramadan, Manzur Muhammad, 'Al-Manahij al-Tajdidiyah fi Tafsir al-Qur'an al-Karim wa Shuruh al-Hadith al-Sharif, Mu'tamar 'Alami 'an Manahij Tafsir al-Qur'an al-Karim wa Sharh al-Hadith al-Sharif, 2/873.

45 Seperti syarah yang dibentangkan dalam kitab Al-Tambid dan Al-Istidhkar (70 jilid) oleh al-Hafiz Ibn 'Abd. al-Bar, Fath al-Bari fi Sharh Sabih al-Bukhari oleh al-Hafiz Ibn Hajar al-'Asqalani dan 'Umdat al-Qari fi Sharh Sahih al-Bukhari oleh Imam Badr al-Din al-'Ayni.

46 Seperti syarah yang dikemukakan oleh Imam al-Nawawi dalam kitabnya Al-Minhaj fi Sharh Sabih Muslim al-Hajjaj dan Shaykh al-Islam Abu Yahya Zakariya b. Muhammad al-Ansari (w. 926 H) dalam kitabnya Tubfat alBari bi Sharh Sabih al-Bukhari. Al-'Azzi, Ahmad b. 'Abd al- Qadir, 'Manahij al-Muhaddithin fi Shuruh al-Hadith', Mu’tamar 'Alami ‘an Manahij Tafsir al-Qur'an al-Karim wa Sharh al-Hadith al-Sharif, 2/925-943.

Rusydiah: Jurnal Pemikiran Islam, Vol. 2, No. 2, Desember 2021 
3. Al-Mujiz, catatan (hashiyah) yang mengungkapkan pengertian hadith dan lafaz secara ringkas. Ia menggarap dan menyimpulkan makna hukum dan faedah fiqh dan nas yang padat. ${ }^{47}$

Penulisan syarah hadith di abad mutakhir lebih bersifat ringkas dan bercorak tematik (mawdu'i). Ia mengetengahkan tema yang berkesan dan mengkhususkan analisis pada maqasid al-hadith tanpa menyentuh secara terperinci tentang ikhtilaf nas. Ia menghuraikan mawdu' dan fikrah hadith secara topikal dan menzahirkan perkaitan antara lafaz yang diungkapkan. Syarahannya diperkukuh dengan hujah dan pandangan yang dirangkul dari ijithad mazhab yang muktabar. ${ }^{48}$

Penulisan kitab syarah yang berkait dengan bentuk hadith yang dibawa terangkum dalam empat bentuk:

1. Kitab yang menghuraikan hadith yang tertentu, seperti hadith Umm Zar'in. ${ }^{4}$

2. Kitab yang menghuraikan hadith dalam bab yang tertentu, seperti hadith hukum. ${ }^{50}$

3. Kitab yang menghuraikan hadith dalam kitab-kitab hadith yang tertentu. ${ }^{51}$

4. Kitab yang menghuraikan kitab-kitab hadith terpilih. ${ }^{52}$

\footnotetext{
${ }^{47}$ Seperti kitab syarah yang diajukan oleh Imam al-Suyuti (w. 911 H), Al-Tawshih fi Sharh al-Jami`al-Sabih dan Al-Dibaj fi Sharh Sabih Muslim bin al-Hajjaj yang menyajikan syarahan singkat (hashiyab) kepada kitab al-Sabihayn.

48 Seperti huraian yang dibentangkan dalam kitab Al-Mufabhim 'ala Mukbtasar Sabih Muslim oleh Dr. 'Abdullah b. 'A'id b. 'A'id Ali Majdu' al-Qarni, Kawkab al-Wahbaj wa Rawd al-Babhaj fi Sharh Sabih Muslim al-Hajjaj oleh Muhammad Amin al-Harari dan Al-Jami' fi Sharb al-Arba'in al-Nawawiyah oleh Abi 'Abdullah Muhammad Yusri.

49 Syarahan terhadap hadith yang tertentu, dengan huraian makna dan dalilnya, seperti kitab Sharh Hadith Umm Zar'in oleh Isma‘il ibn Abi Uways al-Madani (w. 226 H), Bughyat al-Ra'id bima fi Hadith Umm Zar'in min alFawa'id oleh Qadi 'Iyad (476-544 H), Sharh Khal' al-Na'layn oleh Shaykh Muhy al-Din Muhammad b. 'Ali Ibn 'Arabi (w. 638 H), Muntaha al-Amal fi Sharb Hadith Innama al-A'mal oleh Imam al-Suyuti (w. $911 \mathrm{H}$ ), al-Mirqat al'Aliyah fi Sharh al-Hadith al-Musalsal bi al-Awwaliyah, dan Sharh Hadith Umm Zar'in oleh Abi al-Fayd Muhammad Murtada b. Muhammad al-Husayni (w. 1205 H). Kashf al-Zunun, op.cit., 2/1036-1040, Al-Qinnawji, Abjad al-'Ulum, op.cit., 3/12, Al-Kattani, Muhammad b. Ja'far, Al-Risalah al-Mustatrafab li Bayan Masybur Kutub al-Sunnah alMusannafah, ed. oleh Muhammad al-Muntasir Muhammad al-Zamzami al-Kattani, cet. 4 (Beirut: Dar al-Basha'ir alIslamiyah, 1986), h. 82.

${ }^{50}$ Seperti syarah yang dikemukakan terhadap hadith hukum dalam kitab al-Ilmam fi Ahadith al-Ahkam oleh Taqi al-Din Muhammad b. 'Ali Ibn Daqiq al-'Id, dan Matamih al-Afham fi Sharh al-Abkam oleh Abi al-Fadl Qadi 'Iyad al-Yahsubi. Kashf al-Zunun, 2/1718.

51 Huraian hadith dalam kitab-kitab hadith yang tertentu seperti Sharh Sabih Muslim oleh Imam alNawawi, dan Fath al-Bari Sharh Sabih al-Bukhari oleh Ibn Hajr. Fath al-Din Bayanuni, 'Ahammiyah al-Shuruh alHadith wa Qawa'iduha', Mu’tamar 'Alami, 2/958.

52 Sharh Kutub al-Mukhtarat, seperti syarah kitab Riyad al-Salibin dan al-Arba'in oleh Imam al-Nawawi. Ibid.
} 


\section{Jenis-Jenis Syarah}

Antara jenis-jenis syarah yang ditampilkan dalam kitab-kitab syarah yang terhasil termasuklah:

1. Al-Sharh al-Mawdu'i, syarahan yang merangkumi kefahaman tema $\left(\right.$ mawd $\left.u^{\prime}\right)$ yang menggarap maksud lafaz, bab, atau kitab hadith secara khusus. ${ }^{53}$

2. Al-Sharh al-Tahlili, yakni syarahan teks yang membentangkan perbahasan dan kupasan hadith yang komprehensif dan terperinci. ${ }^{54}$

3. Al-Sharh al-Qawli, syarahan yang mengupas dan membahaskan suatu juzuk hadith yang spesifik. ${ }^{55}$

4. Al-Sharh al-Mamzuj, syarahan yang menggandingkan perbahasan isnad dan matan dengan lafaz al-sharih (penghurai) pada satu siyaq. 56

5. Al-Sharh bi'l-Ma'thur, syarahan yang merujuk pada athar dan khabar yang sahih dan hujah yang dinukil dari ijtihad Sahabat (rad), tabi'in, pernyataan (bahasa) 'Arab, syair dan nathr. ${ }^{57}$

6. Sharh li al-Istidlal, syarahan yang merungkai kefahaman dalil (figh aldalil) dan menghuraikan kaedah hukum dan istinbat. ${ }^{58}$

7. Sharh al-Madrasi, syarahan yang dirangka berasaskan keperluan pengajian di peringkat kulliyyah. ${ }^{59}$

53 Al-Ashrafi, Hayfa' 'Abd al-'Aziz Sultani, 'Al-Sharh al-Mawdu'i li al-Hadith al-Sharif: Dirasah Nazariyah Tatbiqiyah', h. 75.

${ }^{54}$ Hamid, Ahmad Muhammad, 'Ilm Sharh al-Hadith wa Marahiluhu al-Tarikhiyah bayna al-Taq'id wa Tatbiq', Mu'tamar 'Alami 'an Manahij Tafsir al-Qur'an al-Karim wa Sharh al-Hadith al-Sharif, h. 1199.

55 Seperti syarahan yang dikemukakan dalam kitab Ma'alim al-Sunan oleh Abu Sulayman al-Khattabi (w. 388 H), Al-Mu'lim bi Fawa'id Muslim oleh Abu 'Abdullah al-Mazari (w. 536 H), dan Badbl al-Majhud fi Hal Sunan Abi Dawnd oleh Ahmad al-Saharanfuri (w. 1346 H). Ahmad 'Abd al-Qadir 'Azzi, 'Manahij al-Muhaddithin fi Sharh al-Hadith', Mu’tamar 'Alami 'an Manahij Tafsir al-Qur'an al-Karim wa Sharh al-Hadith al-Sharif, 2/925-943.

56 Seperti syarahan yang dibentangkan dalam kitab Sharb Sunan Abi Dawnd oleh Ibn Raslan al-Ramli (w. 844), Irshad al-Sari ila Sharh Sabih al-Bukhari oleh Abi al-'Abbas al-Qastalani (w. 923 H), Mirqat al-Mafatih sharh Mishkat al-Masabih oleh Shaykh Nur al-Din 'Ali b. Sultan Muhammad al-Hirawi al-Qari (w. 1014 H) dan Awjaz alMasalik ila Muwatta’ Malik oleh Muhammad Zakariya al-Kandahlawi (w. 1402 H). Ibid. Al-Mubarakfuri, Tubfat alAbwadhi, op.cit., 1/195, Ibn Sayyid al-Nas, Al-Nafh al-Shadhi, 1/91, 'Izzi, Ahmad 'Abd al-Qadir, 'Manahij alMuhaddithin fi Shuruh al-Hadith', h. 925-943.

57 A. Hasan Asy'ari, 'Sejarah dan Tipologi Syarah Hadith', Jurnal Teologia, 19:2 (2008), 340-362.

${ }^{58}$ Seperti syarah yang dikemukakan dalam kitab Ibkam al-Abkam Sharb 'Umdat al-Abkam oleh Ibn Daqiq al-'Id (w. $702 \mathrm{H})$.

${ }^{59}$ Seperti syarah yang dikemukakan dalam kitab al-Misbah al-Munir fi Sharh Ahadith al-Bashir (saw) oleh Shaykh Amin Mahmud Khitab al-Subki (w. 1352 H), dan al-Manhal al-Hathith fi Sharh al-Hadith oleh Prof. Dr. Musa Shahin Lashin. Jenis-jenis syarah yang lain termasuklah Sharh Murattab 'ala Shuyukh al-Musannaf seperti yang dilakarkan dalam kitab al-Tambid oleh Ibn 'Abd al-Bar, dan Sharh Jami' Bayn al-Mawdu'i wa al-Qawli seperti kitab alManhal al-'Adhb al-Mawrud Sharh Sunan Abi Dawud oleh Mahmud Khitab al-Subki. Ahmad 'Abd al-Qadir 'Azzi, op.cit., hal. 933, Humayd, Ahmad b. Muhammad, h. 1223.

Rusydiah: Jurnal Pemikiran Islam, Vol. 2, No. 2, Desember 2021 


\section{Medium Syarah (Aliyat al-sharh)}

Antara instrumen dan mekanisme syarah yang terpenting termasuklah:

1. Penguasaan bahasa Arab, memahami kaedah bahasa dan pengertian lafaz yang sempurna. 60

2. Tawthiq al-nas - mengetahui riwayat dan darjat hadith yang dinyatakan.

3. Pengetahuan yang substantif tentang mawdu' hadith yang dibahaskan.

4. Kesanggupan merungkai ikhtilaf pada riwayat dan lafaz hadith yang dinyatakan. ${ }^{61}$

\section{Adab (Kesenian) Syarah (Adabiyat al-Sharh)}

Antara adab-adab yang signifikan dalam syarah termasuklah:

1. Menzahirkan keikhlasan, ihsan dan taqarrub, dan memperlihatkan kejituan dan kehalusan (itqan) syarah.

2. Berusaha menambah kefahaman, dengan merujuk pada kupasan 'Ulama alMutakhassisun dalam bidang syarah.

3. Menyandarkan pernyataan pada pemiliknya, dan memberi pengiktirafan (credit) terhadap pandangan yang dinukil.

4. Bersifat objektif tanpa terikat dengan pandangan yang ta'asub, dan mempertahankan kebebasan akliah.

5. Kesungguhan dalam meneliti dan mentahqiq hadith-hadith yang disyarah. ${ }^{62}$

\section{Sumbangan Ulama Nusantara di Bidang Syarah}

Dalam catatan sejarah perkembangan Islam di pulau-pulau MelayuIndonesia, naskah-naskah tarikh mencatatkan penulisan dan karya-karya yang terhasil oleh ulama silam dalam pemikiran tasawuf dan metafizik, fiqh dan kalam, dan tidak ketinggalan dalam kajian dan penulisan hadith dan syarah, khususnya di abad-abad ke 16-20 M. Kitab syarah yang terbesar telah dikemukakan oleh

\footnotetext{
${ }^{60}$ Kefahaman lughah ini digariskan oleh Imam Badr al-Din al-'Aini dalam kitabnya Umdat al-Qari yang menguraikan kefahaman lughah, sarf, i'rab, ma'ani, bayan dan tafsir. Al-Khayr Abadi, Muhammad Abu al-Layth, 'Sharh al-Ahadith al-Nabawiyah (saw): Ta'sis wa Tatbiq', Mu'tamar 'Alami, h. 1305.

${ }^{61}$ Ibid, h. 1306.

${ }^{6}$ Al-Khayr Abadi, Muhammad Abu al-Layth, 'Sharh al-Ahadith al-Nabawiyah (saw): 'Ta'sis wa Tatbiq', Mu'tamar 'Alami, op.cit., hh. 1303-5, Kashf al-Zunun, op.cit., 1/37-8, Al-Qinnawji, Abi al-Tayyib Siddiq Hasan, Al-Hittah fi Dhikr al-Sibhah al-Sittah (Beirut: Dar al-Kutub al-Ta limiyah, 1985), h. 101-2.
} 
Shaykh Muhammad Idris 'Abdul Ra'uf al-Marbawi al-Azhari (w. 1989 M) dengan karyanya Bahr al-Madhi Sharh bagi Mukhtasar Sahih al-Tirmidhi. ${ }^{63}$ Kitab ini dianggap antara syarahan terbaik terhadap Sunan al-Tirmidhi yang terus mekar dan berkembang luas di abad mutakhir. ${ }^{64}$

Karya-karya hadith yang terhasil ini menzahirkan pemikiran hadith yang meluas yang dirangkul oleh Ulama Nusantara dalam penghujahan kalam, fiqh, tasawwuf dan akidah yang mendasar. Ia membawakan keterangan-keterangan nas yang terperinci dan komprehensif dalam huraian teks-teks hadith klasik seperti Kutub Hadith al-Tis'ah, kitab Al-Arba'in, Riyad al-Salihin, Bulugh al-Maram, Ihya' 'Ulum al-Din dan beberapa karya lain yang ditulis sekitar ilmu syarah dan mustalah al-hadith. Ini termasuklah kitab:

1. Ilham al-Bari Sharh Sahih al-Bukhari, Sharh Sahih Muslim dan Tajdhib Atraf al-Hadith bi Sharh ma fi Kitab Mukhtar al-Ahadith 65 oleh Al-Ustadh $\mathrm{Hj}$. 'Abdul Halim b. Hj. Noh b. Hj. 'Abdul Hadi b. Mayan Terona (w. 1981 $\mathrm{M})$.

2. Sharh Tarajum Abwab al-Bukhari oleh Abu 'Abdullah Sayyid Hassan b. Nur Hassan (Tok Khurasan) (1875-1944 M).

3. Sharh al-Latif 'ala Arba'in Hadithan li al-Imam al-Nawawi oleh Syaikh 'Abdul Ra'uf b. 'Ali al-Fansuri.

4. Kanz al-Amin fi Sharh al-Arba'in oleh Shaykh Mukhtar b. Ahmad b. Muhammad Zayn al-Kelantani.

5. Fath al-Mubin syarah Hadith Arba'in oleh Sheikh Muhammad Salih b. Muhammad Murid Rawa.

6. Syarah Hadith Empat Puluh oleh 'Asbir b. Ya'qub.

7. Al-Fawa'id al-Bahiyyah fi al-Ahadith al-Nabawiyah (Hidayah al-Habib fi alTarghib wa al-Tarhib) oleh Syeikh Nuruddin Muhammad b. 'Ali b. Hasanji b. Muhammad Hamid al-Raniri (w. 1069 H/1658 M).

${ }^{63}$ Kitab yang menghuraikan sejumlah 2,781 hadith terpilih dalam Jami al-Tirmidhi. Faisal Ahmad Shah, 'Metodologi Penulisan Mohamed Idris al-Marbawi dalam Bahr al-Madhi' (Tesis Ph. D., Jabatan al-Qur'an dan alHadith, Akademi Pengajian Islam, Universiti Malaya, 2007), h. 7. Shaykh al-Marbawi mengungkapkan manhajnya dalam menulis Sharh al-Tirmidhi: "Adalah kemudian daripada sudah aku mengaji kitab yang bernama Sahih alTirmidhi sudahlah jatuh di dalam hatiku berahi dan suka kepadanya oleh aturannya dan kenyataannya pada segala hukum syariat Nabi (saw) kita Muhammad Sallallahu 'alayh wa Sallam. Dengan kerana beribu-ribu bab dan Ahadith serta diikutnya tiap-tiap hadithnya keterangan Imam-Imam mazhab lebih dari mazhab empat yang ma'ruf. Jangan bicara lagi pada sanad hadith itu bukan main lagi diperhalusinya dan lain daripadanya beberapa ilmu." Al-Marbawi, Muhammad Idris 'Abd al-Ra'uf, Bahr al-Madhi li Sharh Mukhtasar Sabih al-Tirmidhi (Damsyik: Dar al-Fikr, t.t.), 1/3.

${ }^{64}$ Al-Marbawi, Muhammad Idris, Bahru al-Madzi syarah Mukhtasar Sabih al-Tirmidhi, 13 jil, dialihbahasa oleh Norainie Abu (Kuala Lumpur: Al-Hidayah Publishers, 2004).

${ }^{65}$ Kitab Mukhtar al-Ahadith karya Sayyid Ahmad al-Hashimi (w. 1362/1943). 
8. Tanqih al-Qawl al-Hathith fi Sharh Lubab al-Hadith oleh Syeikh Muhammad Nawawi b. 'Umar ibn 'Arabi b. 'Ali al-Jawi al-Bantani (1230-1314 $\mathrm{H} / 1814-1897 \mathrm{M}){ }^{66}$

9. Tawfiq al-Bari li Tawdih wa Takmil Masa'il al-Idah li al-Imam al-Nawawi oleh Syeikh Muhammad Nuruddin Marbu al-Banjari al-Makki.

10. Al-Dur al-Mandud Sharh Sunan Abi Dawud dan Fath al-'Allam Sharh Bulugh al-Maram oleh Syaikh Muhammad Yasin b. Muhammad 'Isa alFadani al-Makki.

11. Manhaj Dhawi al-Nazar fi Sharh Manzumah 'Ilm al-Athar dan Al-Khal'at alFikriyah fi Sharh Minnat al-Khairiyah Oleh Syeikh Muhammad Mahfuz b. 'Abdullah b. 'Abd al-Mannan b. 'Abdullah b. Ahmad al-Tarmasi (1285$1338 \mathrm{H} / 1868-1920 \mathrm{M})$.

12. Munir al-Afham Pada Menyatakan Syarah Bulugh al-Maram oleh Syeikh Abu Jabir 'Abdullah b. Ahmad b. Ibrahim b. Muhammad b. 'Abdullah b. Ahmad b. Muhammad al-Qayruwani al-Balawi al-Ghadamsi alMaghribi (1310-1395 H/1892-1975 M).67

\section{Sumbangan Ulama India di Bidang Syarah}

Kajian kitab hadith di akhir abad ke-20 terus mekar dengan kesungguhan luar biasa Ulama-Ulama dari benua India untuk menganalisis dan membahas Kutub Hadith al-Tis'ah. ${ }^{68}$ Kepakaran dan sumbangan pemikir-pemikir hadith seperti Shah Wali Allah al-Dihlawi, Anwar Shah Kashmiri, Mawlana Rashid Ahmad Gangohi, Muhammad Zakariyya al-Kandahlawi, Shaykh Shabbir Ahmad al'Uthmani al-Deobandi (1885-1949 M), Sayyid Abu'l Hasan 'Ali al-Hasani al-Nadwi (1914-1999 M), Hakim al-Ummah Mawlana Ashraf ‘Ali Thanawi (1280-1362 H/1864-

${ }^{66}$ C. Brockelmann, E.J. Brill's First Encyclopaedia of Islam, ed. oleh M. Th. Houtsma et.al. (Leiden, Netherlands: E.J. Brill, 1987), 5/885.

67 Wan Mohd Saghir Abdullah, Khazanah Karya Pusaka Asia Tenggara (Kuala Lumpur: Khazanah Fathaniyah, 1991); Nicholas Heer, A Concise Handlist of Jawi Authors and their Works (Seattle, Washington: t.p., 2006); Azyumardi Azra, Jaringan Ulama Timur Tengah dan Kepulauan Nusantara Abad 17 dan 18 (Bandung: Penerbit Mizan, t.t.), h. 189.

${ }^{68} \mathrm{Hal}$ ini diungkapkan oleh Shaykh Muhammad Rashid Rida (w. 1345/1935): "Sekiranya bukanlah kerana 'inayah saudara-saudara kita Ulama India untuk mengangkat ilmu hadith di zaman ini, nescaya akan terhakislah ia dari penjuru timur, dan telahpun pudar (tradisi) nya di Mesir, Syam, 'Iraq dan Hijaz sejak kurun kesepuluh Hijrah hingga nyata susut di awal kurun keempat belas.” Muhammad Fu'ad 'Abd al-Baqi, Miftah Kunuz al-Sunnah (Lahore: Idarat Tarjuman al-Sunnah, t.t.), h. 3. 
1943 M), Abul A`la al-Mawdudi (1903-1979 M) dan sebagainya telah mengangkat dan memartabatkan warisan dan pemikiran hadith klasik. 69

Perjuangan Ulama India untuk mengangkat dan memperkukuh tradisi pengajian hadith diteruskan dengan usaha Ulama-Ulama besar di abad mutakhir seperti Prof. Dr. Muhammad Mustafa 'Azami yang mengemukakan analisis terperinci terhadap kitab-kitab hadith klasik. ${ }^{70}$ Dr. Abdul Hameed al-Siddiqui turut melakar pengaruh besar dalam bidang hadith dengan usahanya menterjemah kitab-kitab hadith yang muktabar seperti kitab Sahih Muslim ${ }^{71}$ dan Mishkat al-Masabih. ${ }^{72}$ Tokoh-tokoh hadith yang lain termasuklah Dr Muhammad Muhsin Khan, ${ }^{73}$ Prof. Muhammad Hamidullah (1908-2002), ${ }^{74}$ Mawlana Fazlul Karim, ${ }^{75}$ Shaykh 'Ala' al-Din 'Ali al-Muttaqi b. Husam al-Din b. 'Abd al-Malik alHindi (w. 1567 M), ${ }^{76}$ Shah 'Abd al-'Aziz al-Dihlawi (1745-1822), 77 Shaykh Zafar

${ }^{69}$ Al-Husayni, 'Abd al-Hayy b. Fakhr al-Din, Al-I lam bi man fi Tarikh al-Hind min al-A lam al-musamma bi Nuzhat al-Khawatir wa Bahjat al-Sami' wa al-Nawazir (India: Maktabat Dar 'Irfat, 1992); Muhammad Hafiz b. Suruni, 'Juhud al-'Ulama' al-Muslimin fi Sharh Kutub al-Hadith bayna al-Qarn al-Rabi' 'Ashar al-Hijri hatta Awa'il alQarn al-Khamis 'Ashar al-Hijri', Dr. Ahmad b. 'Abd. al-Qadir, 'Manahij al-Muhaddithin fi Shuruh al-Hadith' Mu'tamar 'Alami 'an Manahij Tafsir al-Qur'an al-Karim wa Sharh al-Hadith al-Sharif: Buhuth al-Mu'tamar, ed. oleh Muhammad Abu al-Layth Khayr al-Abadi (Kuala Lumpur: Al-Jami'ah al-Islamiyah al-'Alamiyah, 2007); dan Metcalf, Babara Daly, Islamic Revival in British India: Deoband, 1860-1900 (Princeton, N.J.: Princeton University Press, 1982).

${ }^{70}$ Dalam bukunya A'zami, Muhammad Mustafa, Studies in Early Hadith Literature: With a Critical Edition of Some Early Texts (Indianapolis: American Trust, 1978). Beliau turut mempertahankan ketulenan isnad dan menyangkal tohmahan orientalis dalam bukunya On Schacht's Origins of Muhammadan (saw) Jurisprudence (Riyad: King Sa'ud University, 1985).

71 Terjemahan lengkap yang telah mendapat pengiktirafan meluas dari sarjana Timur dan Barat; berjudul Sabih Muslim: Being Traditions of the Sayings and Doings of the Prophet Muhammad (saw) as Narrated by his Companions and Compiled Under the Title al-Jami' al-Sabih / by Imam Muslim (821-875); Rendered into English by Abdul Hamid Siddiqi; With Explanatory Notes and Brief Biographical Sketches of Major Narrators, cet. 4 (New Delhi: Kitab Bhavan, 1977).

${ }^{72}$ Kitab Mishkat-ul-Masabih / by Wali-ud-Din Mohammad bin 'Abdullah al-Khatib al-Umari al-Tabrizi; Translated and Annotated by 'Abdul Hameed Siddiqui (Lahore: Islamic Publications, 1980) dan The Life of (Prophet) Muhammad (PBUH) (Lahore: Islamic Publications, 1989).

73 Terjemahan kitab Sabih al-Bukhari: The Translation of the Meanings of Sabih al-Bukhari: Arabic-English by Muhammad Mubsin Khan (Madinat al-Munawwarah: Maktabat al-Salafiyah, 1980).

74 Penulisannya dalam ilmu sirah, tafsir, fekah, syariah dan usul al-hadith al-riwayah, dan hasil tahqiqnya terhadap kitab Al-Sahifah al-Sabihah dan Sahifah Hammam ibn Munabbih.

${ }^{75}$ Karya-karyanya yang monumental dan berpengaruh, seperti kitab Al-Hadis: an English translation \& commentary of Mishkat al-Masabih, The Religion of Man dan terjemahan kitab Ibya' Ulumuddin oleh Imam al-Ghazali (1058-1111).

${ }^{76}$ Penyusun kitab Kanz al-'Ummal fi Sunan al-Aqwal wa'l-Af'al.

77 Penulis kitab Bustan al-Muhaddithin. Al-Dihlawi, Shah 'Abd al-'Aziz, Bustan al-Muhaddithin, terj. oleh Muhammad Akram Al-Nadwi, Aisha Bewley (London: Turath Publishing, 2007).

Rusydiah: Jurnal Pemikiran Islam, Vol. 2, No. 2, Desember 2021 
Ahmad 'Uthmani, 78 Fadl Allah al-Hayder Abadi (w. 1399 H), ${ }^{79}$ Shibli Nu'mani, Dr. Muhammad Akram Nadwi ${ }^{80}$, Shaykh Abu Yusuf Riyad al-Haq dan sebagainya. ${ }^{81}$

Sementara Dr. Muhammad Abu'l-Layth al-Khayr al-Abadi turut menyumbangkan kepakaran dalam mentahqiq kitab Sharh Ma'ani al-Athar karya Imam al-Tahawi, Fath al-Bari 82 dan Sahih al-Bukhari dan membincangkan kefahaman usul al-riwayah dan mustalah al-hadith dalam kitabnya, Mu'jam Mustalahat al-Hadithiyah, Takhrij al-Hadith: Nash'atuhu wa-Manhajiyatuhu, 'Ulum alHadith: Asiluha wa Mu'asiruha, Ittijahat fi Dirasat al-Sunnah: Qadimuha wa Hadithuha, risalah Sharh al-Ahadith al-Nabawiyah: Ta'sis wa Tatbiq dan mengemukakan tafsir ringkas surah-surah al-Qur'an dalam kitabnya Rahiq al-Tafasir.

\section{Kitab-Kitab Syarah yang Masyhur}

Antara kitab-kitab syarah hadith yang muktabar dan diperakui secara ijma' sebagai sandaran hukum yang autoritatif termasuklah:

\section{Sharh al-Bukhari 83}

1. I'lam al-Sunan, oleh Abu Sulayman Hamd b. Muhammad b. Ibrahim b. Khitab al-Busti al-Khattabi (w. 388 H/998 M).

2. Sharh Sahih al-Bukhari, oleh Abu al-Hassan 'Ali b. Khalaf b. Battal alMaghribi al-Maliki (w. 449 H).

3. Kashf al-Mushkil 'ala Sahih al-Bukhari, oleh Abu al-Faraj 'Abd al-Rahman ibn 'Ali ibn al-Jawzi (510-597 H/1116-1201 M).

4. Shawahid al-Tawdih wa al-Tasrih li Mushkilat al-Jami' al-Sahih oleh Imam Abu Abdullah Muhammad b. 'Abdullah b. Malik al-Jiyani.

5. Fath al-Bari bi Sharh Sahih al-Bukhari, oleh Ahmad b. 'Ali b. Hajar al'Asqalani (w. 852 H/1372-1449 M) ${ }^{84}$

${ }^{78}$ Penyusun kitab I'la' al-Sunan.

${ }^{79}$ Penyusun kitab Fadl Allah al-Samad fi Tawdih al-Adab al-Mufrad.

80 Penulis kitab Al-Muhaddithat: The Women Scholars in Islam. Muhammad Akram Nadwi, Al-Muhaddithat: The Women Scholars in Islam, 40 jil (London: Interface Publication, 2007).

81 Al-Ghawri, Sayyid 'Abd al-Majid, A'lam al-Mubaddithin fi al-Hind fi al-Qarn al-Rabi' 'Ashar al-Hijri wa Atharibim fi al-Hadith wa Ulumibi (Damsyik: Dar Ibn Kathir, 2000).

${ }^{82}$ Risalah Mukhtarat min Fath al-Bari.

${ }^{83} \mathrm{Kitab}$ Al-Jami' al-Musnad al-Sabih min Umur Rasulillah (saw) wa Sunanibi wa Ayyamibi (saw) karya Imam Abu 'Abdullah Muhammad b. Isma'il b. Ibrahim b. al-Mughirah b. Bardizbah al-Bukhari (194-256 H/810-870 M) yang merangkumkan sejumlah 97 kitab dan 3,450 bab. Ia memuatkan sejumlah 7,275 (atau 7,397) hadith (yang berulang), dan 4,000 hadith tanpa pengulangan, yang terdiri daripada 2,602 hadith mawsul, 1,341 hadith mu'allaq, dan 344 hadith mutaba'at. Al-Nawawi, Sharb Sabih Muslim, 1/129.

${ }^{84}$ Kitab ini telah diringkaskan oleh Imam Muhammad ibn 'Abd al-Wahab (1703-1792 M) dengan huraian singkat dalam karyanya Mukbtasar Fath al-Bari. Terdapat lebih 75 kitab syarah yang mengupas matn Sabih 


\section{Sharh Muslim ${ }^{85}$}

1. Al-Tahrir fi Sharh Sahih Muslim, oleh Imam Muhammad b. Isma'il b. Muhammad b. al-Fadal al-Tamimi al-Asbahani al-Shafi'i (w. 353 H).

2. Sharh Muslim oleh Abi 'Abdillah Muhammad b. Isma'il b. Muhammad alAsfahani (w. $520 \mathrm{H}) .{ }^{86}$

3. Al-Mufhim fi Sharh Gharib Muslim, oleh 'Abd al-Ghafir b. Isma'il al-Farisi (w. $529 \mathrm{H}) \cdot{ }^{87}$

4. Ikmal al-Mu'lim bi Fawa'id Muslim, oleh Abi al-Fadl 'Iyad ibn Musa ibn 'Iyad al-Yahsubi (476-544 H/ $1149 \mathrm{M})$.

5. Al-Mufhim li-ma Ashkala min Talkhis Kitab Muslim, oleh Abi al-'Abbas Ahmad b. 'Umar b. Ibrahim al-Ansari al-Qurtubi (578-656 H/1182-1258 M). ${ }^{88}$

6. Al-Minhaj fi Sharh Sahih Muslim bin al-Hajjaj, oleh Imam Muhy al-Din Abu Zakariyya Yahya ibn Sharaf al-Nawawi (w. 676 H/ 1277 M). ${ }^{89}$

\section{Sharh Jami` al-Tirmidhi}

1. 'Aridat al-Ahwadhi, oleh Abu Bakr ibn al-'Arabi al-Maliki (w. 543 H/1148 M).

al-Bukhari. 'Irar al-Hasani, Ittihaf al-Qari bi Ma'rifat Jubud wa A'mal al-'Ulama' 'ala Sabih al-Bukhari (Damsyik: AlYamamah li al-Taba'at, 1407 H), h. 420-443, Abdal Hakim Murad, Selections from the Fath al-Bari, h. 2, Fath al-Din Bayanuni, 'Ahammiyah al-Shuruh al-Hadithiyah wa Qawa'iduha', Hamid, Ahmad Muhammad, 'Ilm Sharh alHadith wa Marahiluhu al-Tarikhiyah bayna Taq'id wa Tatbiq', Muhammad Sa'ad Siddiqi, 'Manhaj al-Shaykh alKandahlawi fi Sharhihi li Kitab Mishkat al-Masabih', Mu’tamar 'Alami 'an Manahij Tafsir al-Qur'an al-Karim wa Sharh al-Hadith al-Sharif.

${ }^{85} \mathrm{Kitab}$ Al-Musnad al-Sabih al-Mukhtasar min al-Sunan bi Naql al-'Adl 'an al-'Adl 'an Rasulillah (saw) karya Imam Abu al-Husayn Muslim b. al-Hajjaj b. Muslim b. Ward b. Kushan al-Qushayri al-Naysaburi (204-261/821875) yang memuatkan sejumlah 56 kitab dan 1,423 bab. Ia mengandungi 7,748 hadith (yang berulang) dan 3,033 (tahqiq Muhammad Fu'ad 'Abd al-Baqi) atau 4,616 hadith (Mulla Khatir 'Ali) tanpa pengulangan. Antara hasil ringkasan (mukhtasar) kitab Sahih Muslim termasuklah kitab Talkhis Sahih Muslim oleh Abu al-'Abbas al-Qurtubi (w. 656), Mukhtasar Sabih Muslim oleh al-Hafiz Zaki al-Din 'Abd al-'Azim ibn 'Abd al-Qawi al-Mundhiri (1185-1258 M), Mukhtasar Sabih Muslim oleh Abi 'Abd Allah Muhammad b. 'Abd Allah ibn Tarwut (w. $524 \mathrm{H}$ ), Mukbtasar alMusnad al-Sabih li Muslim ibn al-Hajjaj oleh Muhy al-Din Ibn al-'Arabi (w. 633 H), Mukhtasar Abu al-Fadl Muhammad b. 'Abdullah b. Muhammad al-Marsi (w. 655), Mukhtasar Abi 'Ali al-Zayyar, Mukhtasar al-Nawri (w. 656), Mukhtasar'Abd al-Malik al-Kurdi al-Misri (w. 737) Mukhtasar al-Asnawi (w. 763) dan lain-lainnya. Al-Suyuti, Tadrib al-Rawi, h. 104.

${ }^{86}$ Ibn Qadi Syuhbah, Tabaqat al-Shafi'ivyah, 1/338-9.

${ }^{87}$ Haji Khalifah, Kashf al-Zunun, h. 557.

88 Al-Suyuti, Husn al-Muhadarah, op.cit., 1/457, Haji Khalifah, Kashf al-Zunun, 1/558, Fu'ad Sezkin, Tarik.h al-Turath al-'Arabi, 1/212.

${ }^{89}$ Haji Khalifah, Kashf al-Zunun, 1/557-8, 'Abd al-'Aziz b. 'Abdullah, Al-Mu'jam, h. 5, Ibn al-Salah, Siyanah Sabih Muslim, 1/9-17, Al-Imam Muslim fi Dhikra Murur Alf wa Mi'atay Sanah 'Ala Wiladatih (206-1406 H), h. 29. 
2. Al-Nafh al-Shadhi fi Sharh Jami' al-Tirmidhi, oleh Abi al-Fath Muhammad b. Muhammad b. Muhammad ibn Sayyid al-Nas al-Ya'mari (w. 734 H).

3. Sharh Sunan al-Tirmidhi, oleh Imam Abu al-Faraj Zayn al-Din 'Abd alRahman ibn Ahmad ibn 'Abd al-Rahman al-ma'ruf bi ibn Rajab al-Hanbali (736-795 H).

4. Al-Lafz al-Nafi' fi Khatm Kitab al-Tirmidhi al-Jami', oleh Abu al-Khayr Shams al-Din 'Abd al-Rahman al-Sakhawi (831-902 H).

5. Qut al-Mughtadhi, oleh Imam Abu al-Fadl Jalal al-Din al-Suyuti (849-911 H). ${ }^{90}$

\section{Sharh Sunan Abi Dawud ${ }^{91}$}

1. Ma'alim al-Sunan, oleh Abu Sulayman Hamd b. Muhammad al-Busti alKhattabi (w. 386 H). 92

2. Sharh Sunan Abi Dawud (Al-Ijaz) oleh Imam Abu Zakariya al-Nawawi (w. $1277 \mathrm{M})$.

3. Intiha' al-Sunan wa Iqtifa' al-Sunan dan 'Ajalah al-'Alim min Kitab al-Ma'alim oleh Shihab al-Din Abi Muhammad Ahmad b. Muhammad b. Ibrahim b. Hilal al-Maqdisi (w. $765 \mathrm{H}) .{ }^{93}$

4. Badhl al-Majhud fi Hal Sunan Abi Dawud, oleh Mawlana Khalil Ahmad b. Majid 'Ali al-Saharanfuri (w. 1346 H/1927 M).

5. 'Awn al-Ma'bud bi Sharh Sunan Abi Dawud, oleh Abu al-Tayyib Muhammad Ashraf al-Haq al-'Azim Abadi (w. 1329 H). ${ }^{94}$

\section{Sharh Sunan Al-Nasa'i 95}

${ }^{90}$ Ibn Sayyid al-Nas, Al-Nafh al-Shadhi fi Sharh Jami`al-Tirmidhi, 1/70-84.

${ }^{91}$ Kitab al-Sunan yang memuatkan sekitar 4,008 hadith dari sejumlah 500,00 hadith yang dikumpulkan. Ia telah diringkaskan oleh Al-Hafiz Abu Muhammad Zaki al-Din 'Abd al-Azim b. 'Abd al-Qawi al-Mundhiri dengan judul Muktasar Sunan Abi Dawud.

92 Syarahan yang dikemukakan dari riwayat Ibn Dasah. Ahmad 'Abd al-Qadir 'Izzi, 'Manahij alMuhaddithin fi Sharh al-Hadith', Mu'tamar 'Alami 'an Manahij Tafsir al-Qur'an al-Karim wa Sharh al-Hadith alSharif, 2/925-943.

${ }^{93}$ Kashf al-Zunun, 2/1005, Al-Mubarakfuri, Tuhfat al-Ahwadhi, 1/102.

${ }^{94}$ Kitab ini telah dikupas oleh Imam 'Abd al-Tawwab al-Miltani al-Samlatani (w. $1366 \mathrm{H}$ ) dengan judul Ta'liq 'ala 'Awn al-Ma'bud Sharb Sunan Abi Dawud. Al-Barrak, 'Abd Allah b. Salih, Al-Imam Abu Dawud al-Sijistani wa Kitabibi al-Sunan (Riyad: Dar al-Furqan, 1414 H), hh. 67-73, Hamid, Ahmad Muhammad, 'Ilm Sharh al-Hadith wa Marahiluhu al-Tarikhiyah bayna al-Taq'id wa Tatbiq', Mu'tamar 'Alami 'an Manahij Tafsir al-Qur'an al-Karim wa Sharh al-Hadith al-Sharif, h. 1199.

${ }^{95}$ Sunan al-Mujtaba karya Imam Abu 'Abd al-Rahman Ahmad b. 'Ali b. Shu'ayb b. 'Ali b. Sinan b. Bahr b. Dinar al-Nasa’i (215-303/830-915) yang merangkumkan sekitar 5,761 hadith. 
1. Sharh Sunan al-Nasa'i, oleh Imam Siraj al-Din Abu Hafs 'Umar b. 'Ali ibn alMulaqqan al-Shafi'i (w. $804 \mathrm{H}$ ).

2. Al-Qawl al-Mu'tabar fi Khatm al-Nasa'i Riwayat Ibn al-Ahmar dan Buhgyat alRaghib al-Mutamanni fi Khatm Sunan al-Nasa'i, oleh al-Hafiz Shams al-Din Muhammad ibn 'Abd al-Rahman al-Sakhawi (831-902 H).

3. Zahr al-Ruba 'ala al-Mujtaba, oleh Imam Jalal al-Din 'Abd al-Rahman ibn Abi Bakr al-Suyuti (w. $911 \mathrm{H})$.

\section{Sharh Sunan Ibn Majah 96}

1. Al-I'lam bi Sunnatihi 'Alayh al-Salat wa al-Salam, oleh al-Hafiz 'Ala' al-Din Abu 'Abdullah Mughlatay al-Bakjari al-Hakri al-Hanafi (w. 762 H).

2. Ma Tamassu Ilayh al-Hajah 'ala Sunan Ibn Majah, oleh Siraj al-Din Abu Hafs 'Umar b. 'Ali b. al-Mulaqqan (w. $804 \mathrm{H}$ )

3. 'Ujalah al-Darurat wa al-Hajah 'ala Khatm Sunan Ibn Majah, oleh al-Hafiz Muhammad b. 'Abd al-Rahman al-Sakhawi (w. 902 H).

4. Misbah al-Zujajah 'ala Sunan Ibn Majah, oleh Imam Jalal al-Din 'Abd alRahman ibn Abi Bakr al-Suyuti (w. 911 H). ${ }^{97}$

\section{Sharh al-Muwatta' 98}

1. Sharh al-Muwatta', oleh 'Abd al-Malik b. Habib b. Sulayman al-Maliki alQurtubi (w. $239 \mathrm{H})$.

2. Al-Maw'ib fi Sharh al-Muwatta' oleh Abu al-Walid b. al-Saffar Yunus b. Mughith.

96 Sunan al-Mustafa (saw) karya Imam Abu 'Abdullah Muhammad b. Yazid ibn Majah al-Qazwini (209273 H/886 M) yang memuatkan sejumlah 4,341 hadith (ditahqiq oleh Muhammad Fu'ad Abd al-Baqi) atau 4,397 hadith (Muhammad Mustafa al-A'zami) yang dikemukakan dalam 32 kitab dan 1,500 bab. 3,002 hadith darinya telah dikeluarkan dalam Kitab Sabih al-Bukhari, Muslim, Sunan al-Tirmidhi, Abi Dawud, dan al-Nasa'i. Khatib alBaghdadi, Tarikh Baghdad, op.cit., 7/453, Ibn Hajar, Tabdhib al-Tahdhib, 9/531, Ibn Kathir, Al-Bidayah wa al-Nibayah, $11 / 52$.

${ }_{97}$ Al-Mubarakfuri, Tuhfat al-Ahwadhi, op.cit., 1/106-8, Al-Bahuth, Yusuf b. 'Abd Allah, 'Manhaj al-Imam al-Hafiz 'Ala' al-Din Mughlatay al-Hanafi fi Sharhihi li Sunan Ibn Majah', Mu'tamar 'Alami 'an Manahij Tafsir alQur'an al-Karim wa Sharh al-Hadith al-Sharif, op.cit.

${ }^{98}$ Kitab Al-Muwatta' karya Imam Abu 'Abdullah Malik b. Anas b. Abi 'Amir b. 'Amru Abu al-Harith alAsbahi (rad) (73-177/798) yang mengemukakan sejumlah 1,720 hadith merangkumi 600 hadith musnad, 222 hadith mursal, 613 hadith mawquf dan 285 hadith maqtu'. Muhammad b. 'Allan, Muhammad 'Ali al-Bakri, Al-Futuhat alRabbaniyah' ala al-Adhkar al-Nawawiyah, ed. oleh 'Abd al-Mun'im Khalil Ibrahim (Beirut: Dar al-Kutub al-'Ilmiyah, 2004), h. 95.

Rusydiah: Jurnal Pemikiran Islam, Vol. 2, No. 2, Desember 2021 http://ejournal.stainkepri.ac.id/index.php/rusydiah 
3. Al-Imla' fi Sharh al-Muwatta', oleh Abu Muhammad 'Ali ibn Ahmad ibn Sa'id ibn Hazm al-Zahiri (384-456 H/994-1064 M).

4. Al-Istidhkar, dan Al-Tamhid lima fi al-Muwatta' min al-Ma'ani wa'l-Asanid, oleh Abi ‘Umar Yusuf ibn 'Abdullah b. Muhammad b. 'Abd al-Bar al-Namari alQurtubi (463 H/ 978-1071 M).

5. Awjaz al-Masalik ila Muwatta' al-Imam Malik, oleh Ra'is al-Muhaddithin Muhammad Zakariyya b. Muhammad b. Yahya al-Kandahlawi al-Madani $(1315-1402 \mathrm{H}) .{ }^{99}$

\section{KESIMPULAN}

Kertas ini telah mengutarakan perbincangan yang ringkas tentang ilmu syarah hadith dan menyorot latar sejarah dan perkembangannya sejak kurun pertama Hijrah. Ia menjelaskan manhaj syarah yang dilakarkan oleh Ulama dalam penelitian dan perbincangan teks-teks hadith yang komprehensif. Disiplin syarah dan madkhalnya kini telah diangkat dalam pengajian hadith di dunia Islam yang tuntas menggarap ide dan kefahaman hadith dan syarah yang ekstensif. Kertas ini turut memperlihatkan kerangka besar metode syarah yang diketengahkan oleh para ulama dalam mengupas karya-karya hadith klasik dan kontemporer yang autoritatif. Sumbangan Ulama hadith ini haruslah dikembangkan dalam konteks perkembangan tradisi intelektual Islam bagi mengangkat warisan pemikiran hadith dan syarah dan mempertahankan legasinya di abad mutakhir.

\section{DAFTAR PUSTAKA}

Ahmad b. 'Abd. al-Qadir, 'Manahij al-Muhaddithin fi Shuruh al-Hadith', dalam Mu'tamar 'Alami 'an Manahij Tafsir al-Qur'an al-Karim wa Sharh al-Hadith al-Sharif: Buhuth al-Mu'tamar, ed. oleh Muhammad Abu al-Layth Khayr alAbadi (Kuala Lumpur: Al-Jami'ah al-Islamiyah al-'Alamiyah, 2007)

Al-Ahdab, Khaldun Muhammad Salim, 'Al-Tasnif fi al-Sunnah al-Nabawiyah min Bidayat al-Muntasif al-Thani li al-Qarn al-Rabi' 'Ashar al-Hijri ila al-Waqt al-Hadir: 'Ard Tarikhi', dalam Nadwah 'Inayah al-Mamlakah al-'Arabiyah alSu'udiyah bi al-Sunnah wa al-Sirah al-Nabawiyah (saw) (Saudi Arabia, 2004)

${ }^{99}$ Untuk perbahasan lanjut, sila rujuk Al-Kandahlawi, Muhammad Zakariya, Awjaz al-Masalik ila Muwatta' Malik (Beirut: Dar al-Fikr, t.t.), 1/113; Muhy al-Din 'Atiyah, op.cit., Al-Ahdab, Khaldun Muhammad Salim, 'AlTasnif fi al-Sunnah al-Nabawiyah min Bidayat al-Muntasif al-Thani li al-Qarn al-Rabi" 'Ashar al-Hijri ila al-Waqt al-Hadir: 'Ard Tarikhi', dalam Nadwah 'Inayah al-Mamlakah al-'Arabiyah al-Su'udiyah bi al-Sunnah wa al-Sirah alNabawiyah (saw) (Saudi Arabia, 2004). 
Al-Arniqi, Muhammad b. Qutb al-Din al-Rumi, Madinat al-'Ulum (Beirut: Dar alKutub al-'Ilmiyah, 1978)

Al-Ashrafi, Hayfa' 'Abd al-'Aziz Sultani, 'Al-Sharh al-Mawdu'i li al-Hadith alSharif: Dirasah Nazariyah Tatbiqiyah' (Tesis M.A., Kulliyyah Ilmu Wahyu dan Sains Kemanusiaan, Universiti Islam Antarabangsa Malaysia, 2007)

Al-Dihlawi, Shah 'Abd al-'Aziz, Bustan al-Muhaddithin, terj. oleh Muhammad Akram Al-Nadwi, Aisha Bewley (London: Turath Publishing, 2007).

Al-Ghawri, Sayyid 'Abd al-Majid, A'lam al-Muhaddithin fi al-Hind fi al-Qarn al-Rabi' 'Ashar al-Hijri wa Atharihim fi al-Hadith wa 'Ulumihi (Damsyik: Dar Ibn Kathir, 2000)

Al-Kandahlawi, Muhammad Zakariya, Awjaz al-Masalik ila Muwatta' Malik (Beirut: Dar al-Fikr, t.t.)

Al-Khatib al-Baghdadi, Abu Bakr Ahmad b. 'Ali b. Thabit, Al-Jami' li Akhlaq al-Rawi wa Adab al-Sami', ed. oleh Mahmud al-Tahhan (Riyad: Maktabah al-Ma'ari, $1403 \mathrm{H})$

Al-Mubarakfuri, Abu al-'Ala Muhammad 'Abd al-Rahman b. 'Abd al-Rahim, Tuhfat al-Ahwadhi bi Sharh Jami' al-Tirmidhi (Beirut: Dar al-Kutub al-'Ilmiyah, t.t.)

Al-Razi, Muhammad b. Abi Bakr, Mukhtar al-Sihhah (Beirut: Maktabah Lubnan, 1987)

Fayruz Abadi, Muhammad b. Ya'qub, Al-Qamus al-Muhit (Beirut: Mu'assasah alRisalah, 1987)

Fath al-Din Bayanuni, 'Ahammiyah al-Shuruh al-Hadith wa Qawa'iduha', dalam Mu'tamar 'Alami ‘an Manahij Tafsir al-Qur'an al-Karim wa Sharh al-Hadith al-Sharif, ed. oleh Muhammad Abu al-Layth Khayr al-Abadi (Kuala Lumpur: Al-Jami'ah al-Islamiyah al-'Alamiyah, 2007)

Hajji Khalifah, Mustafa ibn 'Abd Allah, Kashf al-Zunun 'an Asami al-Kutub wa alFunun (Beirut: Dar al-Fikr, 1990)

Ibn al-Athir, Majd al-Din al-Mubarak ibn Muhammad, Al-Shafi fi Sharh Musnad alShafi'i, ed. oleh Ahmad b. Sulayman dan Abi Tamim Yasir b. Ibrahim (Riyad: Maktabat al-Rushd, 2005)

Ibn Manzur, Abu al-Fadl Jamal al-Din Muhammad b. Mukarram, Lisan al-'Arab (Beirut: Dar Sadir, 1990)

Ibn Sayyid al-Nas, Muhammad al-Ya'mari, Al-Nafh al-Shadhi fi Sharh Jami' alTirmidhi, ed. oleh Ahmad Ma'bad 'Abd al-Karim (Riyad: Dar al-'Asimah, $1409 \mathrm{H})$ 
Kurniati, Yunita, 'Rekonstruksi Metodologi Keilmuan Syarah Hadis Klasik', Islam Transformatif: Journal of Islamic Studies, 4.1 (Januari-Juni 2020), 46-56.

Khayr Abadi, Muhammad Abu al-Layth, 'Ulum al-Hadith Asiluha wa Mu'asiruha, cet. 4 (Selangor: Dar al-Shakir, 2004)

Metcalf, Barbara Daly, Islamic Revival in British India: Deoband, 1860-1900 (Princeton, N.J.: Princeton University Press, 1982)

M.N, Siti Fadzilah, et al., 'Teknik Visualisasi Maklumat Syarah Hadis', Journal of Hadith Studies, 3.1 (June 2018), 19-35

Nadwi, Muhammad Akram, Al-Muhaddithat: The Women Scholars in Islam, 40 jil (London: Interface Publication, 2007)

Sagir, Akhmad, 'Perkembangan Syarah Hadis dalam Tradisi Keilmuan Islam', Ilmu Ushuluddin, 9.2 (Juli 2010), 129-151

Supian, Aan, 'Metode Syarah Fath al-Bari (Studi Syarah Hadis Pada Bab Halawah al-Iman)', Nuansa, X.1 (Juni 2017), 24-34 